\title{
Poetic Law and the Medieval Irish Linguist: Contextualizing the Vices and Virtues of Verse Composition in Auraicept na nÉces
}

\author{
DEBORAH HAYDEN \\ Department of Anglo-Saxon, Norse and Celtic, University of Cambridge, UK
}

Doctrine concerning the faults and correctives of poetic composition in the medieval Irish grammatical treatise Auraicept na nÉces, 'The Scholars' Primer', illuminates not only our understanding of the Auraicept's complex textual transmission, but also aspects of the relationship between linguistic and legal learning in early Ireland. This contribution examines parallels between the Auraicept's stylistic teaching and similar material found in other texts from the medieval Irish literary canon, and considers the significance of this doctrine in relation to the literary portrayal of satire as a potential regulatory force in society. Against this background, it compares the arrangement of material pertaining to stylistic devices in two distinct manuscript copies of the Auraicept that have previously been identified as belonging to separate recensions. It is argued that such a preliminary investigation may serve as a useful diagnostic to highlight some of the issues involved in a larger-scale study of the Auraicept's textual transmission.

KEYWORDS Auraicept na nÉces, Bretha Nemed Dédenach, early Irish law, language study, Latin grammars, medieval Ireland, poetry, rhetoric, satire

It is the purpose of the present discussion to examine one aspect of the linguistic doctrine found in the medieval Irish treatise Auraicept na nÉces, 'The Scholars' Primer', a work written primarily in the Irish vernacular and ostensibly intended as a manual for the rudimentary instruction of poets-in-training. ${ }^{\mathrm{I}}$ In particular,

\footnotetext{
I I am grateful to the Society for the Study of Medieval Languages and Literature for funding the research trip to the Dublin Institute for Advanced Studies, School of Celtic Studies which allowed me an opportunity to complete this article. I also owe thanks to Anders Ahlqvist, Denis Casey, Thomas Charles-Edwards, Paul Russell, and an anonymous reader for offering many helpful comments and suggestions on previous drafts. Like the poets whose compositional flaws are the subject of what follows here, I alone bear full responsibility for any remaining errors or omissions.
} 
this contribution aims to show how a closer look at the manuscript context of the Auraicept's accreted didactic commentary outlining the various faults and correctives of verse composition might not only contribute to our understanding of that treatise's complex textual transmission, but also illuminate aspects of the relationship between linguistic and legal learning in the medieval Irish period. This latter connection is especially manifest in the literary portrayal of satire composition as a potential regulatory force in society. It is beyond the scope of this investigation to engage in a close reading of the Auraicept commentators' terminological usage in their treatment of stylistic devices, although this would be a very fruitful avenue of inquiry to build on the foundation of previous scholarship in this area. ${ }^{2}$ Instead, this study will consider the relationship of the Auraicept's stylistic doctrine to similar material found in other texts from the medieval Irish literary canon, and will then compare the manner in which this material has been incorporated into two manuscript copies of the Auraicept that have previously been identified as belonging to separate recensions. This latter endeavour can only claim to be a preliminary one at best, as a complete understanding of the Auraicept's textual transmission awaits a comprehensive, up-todate, and detailed study of all its known manuscript copies. ${ }^{3}$ However, even an introductory analysis of the Auraicept commentary's structure and relationship to other texts can reveal interesting aspects of its medieval authors' conception of linguistic study as a learned discipline, as well as the extent to which they conceived of the Auraicept itself as a unified, integral work.

Auraicept na nÉces consists of a short, so-called 'canonical' core that has been dated by Anders Ahlqvist (1983: 36) to 'a fairly early stage' of the Old Irish period, the typical linguistic classification referring to the vernacular of $c .700$ to c. 900 AD. To this core was added a great deal of commentary over the course of the next several hundred years, even until the composition of some of the earliest extant manuscript witnesses of the Auraicept around the fourteenth century, and indeed beyond this point. ${ }^{4}$ Such continued scribal activity, as well as the substantial number of copies of the text itself and of related material that have survived to the present day, testify to the sustained popularity and perceived importance of the Auraicept amongst early Irish scholars over an extended period. ${ }^{5}$ The contents and structure of

2 See for example Meroney (1953-58), Kalyguine (1993), Hollo (1996), and Sims-Williams (2005).

3 The most recent analysis of the Auraicept manuscripts is that undertaken by Anders Ahlqvist (I983: 22-35). However, he acknowledges that his work is only an initial attempt, and that a more comprehensive account remains a desideratum.

4 Ahlqvist (1983: 47-5I) has produced an edition and translation of what would seem to be the original core of the Auraicept, although the complexity of the text's transmission means that his work is not necessarily definitive. At present the only published edition of both the core text and its accreted scholia is that by George Calder (I917). However, Calder's text is based on just a few of the numerous copies of the Auraicept that are now known to exist, and his translation of what he designates as the 'short' version of the treatise is wanting in several respects.

5 Hofman (2000: 278-85) noted that the esteem in which the Auraicept was held is further evidenced by the fact that it is mentioned in a Middle Irish poem datable to $c$. I050-II 50 which enumerates the most important texts and authors of Ireland. For an edition and translation of this poem see Smith (I994). 
the treatise's core and its accreted commentary imitate the didactic methods of Latin grammarians like Donatus and Priscian, who are cited frequently, and it is clear that the Auraicept was composed in an intellectual milieu similar to that which produced numerous other Hiberno-Latin grammars, biblical exegeses, and vernacular legal texts, to which its contents and methodology of composition show significant similarities. Indeed, Auraicept na nÉces in many ways bears witness to the now established argument that, as Dáibhí Ó Cróinín has put it, 'Irish computists, exegetes, hagiographers and even grammarians drew on a common body of materials; the separation of these disciplines is a modern departure from medieval practice' (1983a: 240).

The term Auraicept, meaning something like a 'Primer', ${ }^{6}$ suggests that the work belongs to a genre of basic textbook-style compositions which also includes many tracts concerned with legal matters. This genre appears to be derived from Latin grammatical manuals, which would have been used in the schools established by most of the principal churches in Ireland and run by ecnai - a term most often translated as 'learned men' or 'ecclesiastical scholars' - whose educational training consisted of both grammar and exegesis.7 Thus the Auraicept's basic structural framework consists of elementary linguistic precepts explicated by an array of historical and literary allusions, typically in the form of etymological analyses of lemmata drawn from the core text. ${ }^{8}$ Indeed, recent scholarship has acknowledged not only the Auraicept's debt to Hiberno-Latin grammatical treatises (Poppe, I999; 2002), but also its more general situation within the critical and pedagogical programme of medieval grammatica. ${ }^{9}$ This discipline was understood throughout antiquity and the medieval period as the art which deals with correct speaking and explication of literature, although Anneli Luhtala has noted how in the Carolingian schools the study of grammar assumed more theoretical dimensions, encroaching upon the territories of the other arts of discourse, dialectic and rhetoric' (I995: II5). As the following study will show, a consciousness of the changing relationships between these verbal disciplines is relevant to our understanding of the Auraicept's accreted commentary.

\section{The medieval Irish poet and the Auraicept's pedagogical purpose}

While considering the Auraicept's debt to the broader aims of classical and medieval literary theory, it should also be recognized that the treatise's primary function as a basic linguistic manual for aspirants to the poetic profession places it within a

\footnotetext{
6 See the discussions by Burnyeat (2007: I88-94) and Breatnach (1987: 78).

7 See for example Charles-Edwards (I998: 74-75 and 2000: 267). For a provisional survey of classical and secular Latin sources known to the Irish before $c$. AD 800, see Herren (I98I).

8 On medieval etymological method generally see Amsler (I989); for the Irish context see Baumgarten (2004) and Russell (2004).

9 Burnyeat (2007) has developed further the views of Poppe (I996). Both studies illuminate how the Auraicept attests to Ireland's participation in the broader context of literary theory and pedagogical tradition as discussed by Irvine (1994).
} 
specific social and pedagogical context. ${ }^{\text {I0 }}$ Some remarks on the literary and legal evidence for the role of poets and poetry in medieval Ireland are thus an important preliminary to a discussion of the commentary on verse faults and correctives in Auraicept na nÉces.

Our surviving sources portray medieval Irish poets as members of a privileged class who counted among the few members of society allowed, albeit within the confines of carefully delineated terms, to travel and work in political territories other than their own. ${ }^{\text {II }}$ This resulted in what appears to have been a highly organized network of literate élite throughout Ireland, and (bearing in mind both the paucity of some extant source material and the frequently prescriptivist perspective of those few individuals engaged in authorial activity) a literary language which is remarkably lacking in dialectal variation. ${ }^{22}$ Much of our knowledge of the poetic profession stems from a collection of legal status-texts which are written in the vernacular and frequently referred to by modern scholars as 'poetico-legal' in nature, due to their general emphasis on the social standing of poets and on the various benefits that these craftsmen might acquire through the exercise of their artistic skill. The status-texts portray a system where a poet-in-training could advance through a series of grades, entitling him to travel with retinues of various sizes and to receive ever more substantial compensation in the case of insult. Upward progression on this professional ladder required, however, that a poet demonstrate his ability to compose in an increasingly large and diverse range of metres.

One example of the poetico-legal genre in question is the relatively concise tract entitled Uraicecht na Riar, 'The Primer of the Stipulations', which is concerned with outlining the privileges and responsibilities associated with each of the various grades of poets; an example of this text is shown in Figure $\mathrm{I}^{\mathrm{I}}{ }^{\mathrm{I}}$ Uraicecht na Riar reveals how a talented poet could enjoy considerable rewards in exchange for compositions

\footnotetext{
ro A good introduction to this context is that by Sims-Williams and Poppe (2005).

II The word used to refer to this class is nemed, meaning an individual (or group of individuals) possessing exalted legal status or privileges. Its Gaulish cognate nemeton means 'a consecrated place', however, and the Irish reflex therefore has associations of sacrality. Other members of society typically designated as nemed include kings, lords, and clerics; poets were the only lay professionals who could lay claim to such status. For further discussion of the term nemed see McCone (1984). The legal constraints imposed upon poets venturing into foreign territory are treated by Breatnach (2004).

I2 This apparent uniformity may, of course, simply be a result of source survival and the limited extent of literacy amongst the medieval Irish population as a whole. Given the multiplicity of small kingdoms in Ireland at this period and the geographical (and, for some, social) obstacles which hindered travel between territories, it is hard to imagine that dialectal variation did not exist. On this issue see especially Charles-Edwards (I995: 722-29), McCone (1989: 57-97), and Russell (2005: 439-50).

${ }^{\text {I3 }}$ Uraicecht na Ríar is at present the most accessible of the poetico-legal texts thanks to the annotated edition and translation produced by Breatnach (I987). The introduction and appendices to Breatnach's edition also include discussion and translations of sections from several related texts, such as Uraicecht Becc 'The Small Primer', Míadślechta 'Rank Sections', and Bretha Nemed 'Judgements of Privileged (or Professional) Persons'. Gerald Manning is currently completing an edition of Uraicecht Becc at the Dublin Institute for Advanced Studies.
} 


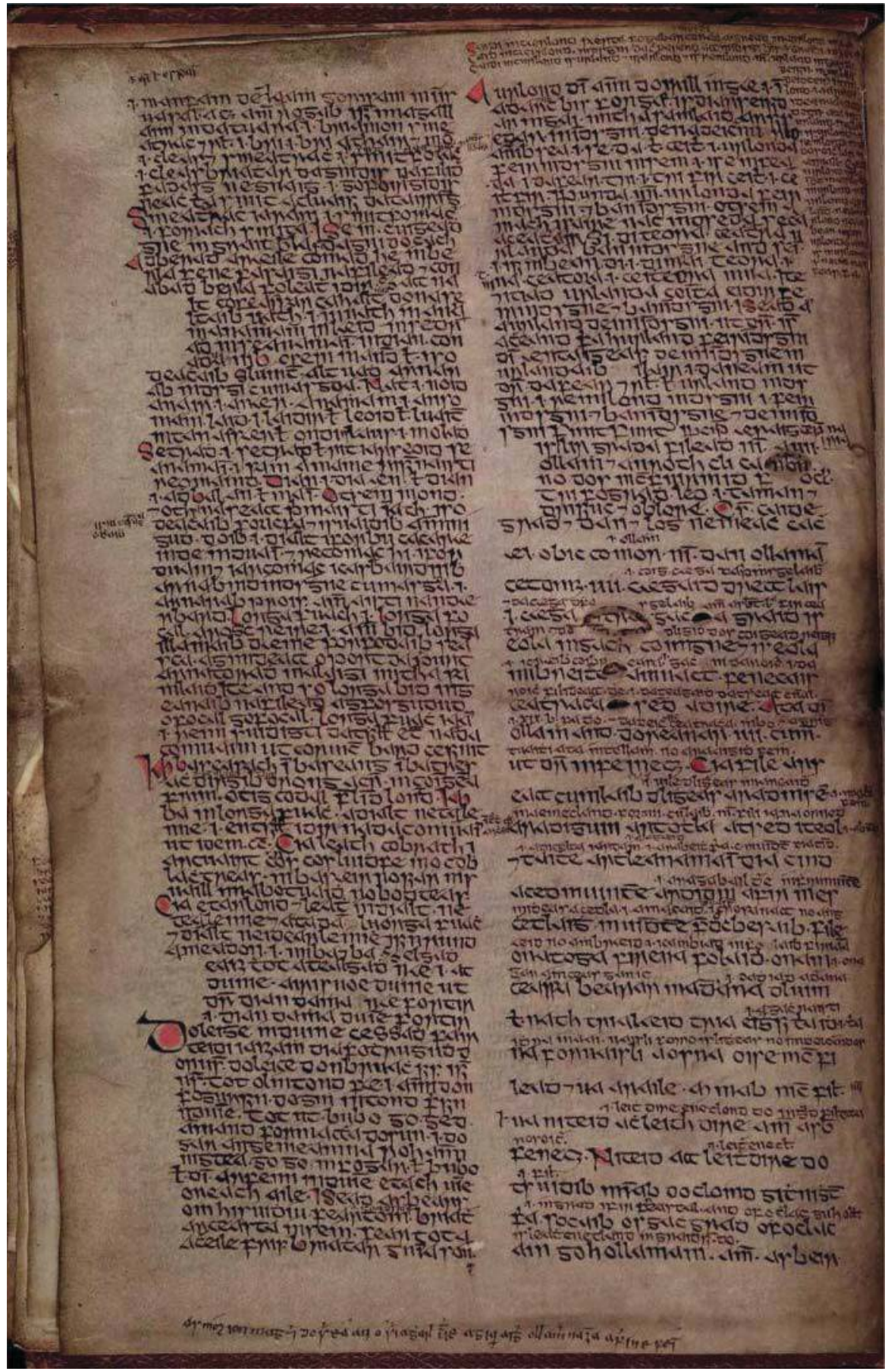

FIGURE 1 The end of Auraicept na nÉces followed by the incipit of Uraicecht na Riar in Dublin, Trinity College Library 1432 (E. 3. 3), p. 16 (D).

Image reproduced by permission of Trinity College Dublin (c) The Board of Trinity College Dublin 
he offered to a patron, but specifies that such wealth might only be obtained as the result of many years of intense study and the achievement of technical mastery. Moreover, just as a well-crafted poem could entail substantial remuneration, offering a composition that was in some way technically flawed could incur the undesirable consequence that a patron might, by legal right, withhold payment from the poet in his employ. ${ }^{\mathrm{I}}$ The potentially grave consequences of such a system resulted, unsurprisingly, in the pedagogical need to articulate a set of ground-rules for poetic composition. In legal terms, poems were the merchandise at stake in a binding contract established between poet and patron, where the poet was entitled to a specified amount of compensation in return for his literary 'goods'; the articulation of stylistic rules for literary compositions thus served the obvious purpose of establishing the terms by which the merchandise might be deemed faulty or otherwise. The likelihood was, of course, that other trained poets would be the first to recognize technical flaws in a rival artist's compositions, thus motivating the need for poets to maintain the quality of their wares in what was no doubt a competitive entertainment market. ${ }^{\mathrm{I5}}$

In keeping with classical rhetorical tradition, many of these compositional rules echo the Peripatetic ideal of seeking a relative mean of appropriateness between two extremes of deficiency and excess. This principle of moderation found expression in later rhetorical discourse as the definition of correct and faulty forms for every compositional style, where an exemplary work was characterized by its successful avoidance of either a dearth or an excess of stylistic ornaments, but where a stylistic feature condemned as a fault in one literary register might also be considered a quality when used in another context. The frequent association of 'vice' and 'virtue' with the fault/corrective dichotomy of classical stylistic doctrine might be traced to the definition of these two themes as the special topics of invention for epideictic or demonstrative oratory, of which the corresponding 'purposes' are vituperatio 'blame' and laudatio 'praise'. ${ }^{16}$ It is well established, of course, that medieval Ireland's familiarity with classical rhetoric would have been transmitted through the medium of Latin tradition, particularly via grammatical, poetic and encyclopaedic manuals. ${ }^{17}$ Thus Isidore's Etymologiae, a work which enjoyed considerable prestige in Ireland from a very early period, summarizes the ancient rhetoricians' account of oratio demonstrativa as the oratorical branch in quo laudabilis persona aut reprehensibilis ostenditur, ${ }^{18}$ and then proceeds to specify the compositional qualities that should be

\footnotetext{
I4 This is specified in a law-text published by Thurneysen (I927: I77 and I8I).

${ }^{15}$ For a more detailed discussion of the nature of contracts between poets and patrons, see Breatnach (I983).

${ }^{16}$ Aristotle, Rhetorica I.3 (Freese, I947: 32-39).

${ }^{17}$ On the issue of Irish scholars' very limited knowledge of Greek language and literary works in the medieval period, see for example Esposito (I9I2), Ahlqvist (I988), and Russell (2000). O'Riordan (2007: 25-26) discusses the possible influence on medieval Irish bardic scholarship of artes poetriae such as the Ars Versificatoria of Matthew of Vendôme, the Poetria Nova of Geoffrey of Vinsauf, and the Parisiana Poetria of John of Garland, all composed between the late twelfth and early thirteenth centuries.

${ }^{\text {I8 }}$ Meroney (I953-58: 70-76); Isidore, Etymologiae II.iv.I (Lindsay, I9II).
} 
sought by orators along with the kinds of faults, or vices, which they should avoid, stating that purum et honestum oratoris eloquium carere debet omnibus vitiis tam in litteris, quam in verbis, quam etiam in sententiis. ${ }^{19}$

In an Irish context, this dichotomy between vice and virtue as both the means and the subject of artistic composition is evident from the literary emphasis placed on praise and satire as the prerogative of medieval Irish poets. ${ }^{20}$ This is perhaps most clearly expressed in the aphoristic ninth-century wisdom-text Trecheng Breth Féne: ${ }^{21}$

Cetheora miscne flatha: .i. fer báeth utmall, fer dóer dímáin, fer gúach esindraic, fer labor dísceoil; ar ní tabair labrai acht do chethrur: .i. fer cerda fri háir 7 molad, fer coimgni cuimnech fri haisnéis 7 scélugud, brethem fri bretha, sencha fri senchas.

Four hatreds of a chief: a silly flighty man, a slavish useless man, a lying dishonourable man, a talkative man who has no story to tell. For a chief does not grant speech save to four: a poet for satire and praise, a chronicler of good memory for narration and story-telling, a judge for giving judgments, an historian for ancient lore. ${ }^{22}$

Other literary and legal sources detail the degree to which the composition of satirical verse in particular was a greatly feared poetic practice in medieval Ireland, depicting it as a kind of verbal assault which, by ridiculing or shaming its subject, had the magical power to inflict physical wounds or blemishes on its victims. Such power could have significant consequences in medieval Ireland's hierarchical and inegalitarian society, the legal workings of which revolved around recognition of the individual's lóg n-enech, or 'honour-price', understood as the compensation due if

I9 Isidore, Etymologiae II.xix.r (Lindsay, I9II). On Ireland's early use of Isidore, see Herren (I980).

${ }^{20}$ On this subject see especially Breatnach (2006). The most comprehensive study of medieval Irish satire of recent date is that by McLaughlin (2008).

${ }^{21}$ Meyer (1906: 32-33, $\$ 248$ ); the title literally means 'A Triad of Judgments of the Irish'. This text, in which the cited passage is an exception to the usual triadic structuring of gnomic statements, belongs to a corpus of early Irish sententious material, some of which is written in highly stylized, rhetorical prose and seems to bear a relationship to poetico-legal texts such as Uraicecht na Ríar. For example, the tract on the duties and responsibilities of kingship entitled Audacht Morainn, 'The Testament of Morann', exhibits stylistic similarities to this poetic material and conveys its maxims on correct rule through legendary authority figures who are also cited frequently in texts of the Bretha Nemed school. For editions and discussion, see Ahlqvist (I984; 1987), Kelly (1976), and Thurneysen (I9I7). The maxim given here also occurs in the pseudo-historical prologue to the collection of law-tracts entitled Senchas Már, which adds that after the arrival of Patrick in Ireland, all of these forms of 'authoritative speech' became subject to the possessor of the so-called bérla bán, 'white language', understood as the language of the Scriptures: on this text see Carey (I994: I2 and I9).

${ }^{22}$ Meyer's translation does not do justice to the legal force behind some of the terms used in this triad. For example, báeth (translated here as 'silly') can also refer to an individual who is considered legally incapacitated on mental grounds, and therefore not fully responsible for his actions (either through nonage or mental deficiency). Dóer (translated as 'slavish') is the legal term for an unfree individual, or serf; in the law-tracts it is primarily opposed to sóer, 'free', a distinction of considerable importance in the medieval Irish social hierarchy. For an alternative translation of part of this triad see Stacey (2007: 154). 
one should suffer injury or offence. Indeed, as has been evidenced above by Uraicecht na Riar, it is the nature and amount of compensation owed to various individuals that forms the central subject-matter of many of the medieval Irish law-tracts. In the case of poets, unjustified satire could entail payment of the victim's honour-price, whereas justified satire could be used to pressure people into obeying the law by threatening them with the loss of their log n-enech. This suggests that poets were — or at least presented themselves as being — individuals who contributed significantly to the regulation of the social hierarchy and to the maintenance of its legal principles. $^{23}$

A striking illustration of satire composition is incorporated into the penultimate section of Uraicecht na Ríar in the form of a vindictive verse directed against Caíar, a legendary king of Connacht. The satire follows a statement about why poets are entitled to nemed 'sacred' or 'privileged' status: ${ }^{24}$

Ceist, cid ara n-eipertar nemid donaib grádaib-seo? Ní hansae, ar nemchumscugud di ulc friu, fo bíth na haíre tri bricht do-rigni Néide do Chaíar ríg Connacht, do bráthair a athar. Is sí ind áer:

Maile, baire, gaire Caíar,

cot-mbéotar celtrai catha Caíar,

Caíar di-bá, Caíar di-rá - Caíar! $!^{25}$

fo ró, fo mara, fo chara Caíar!

Why are the members of these grades called nemed? Not difficult; because of the non-transference of wrong to them, as a result of the satire with a spell which Néide made against Caíar, king of Connacht, his father's brother. The satire is:

Evil, death, short life to Caíar, spears of battle will have killed Caíar, May Caíar die, may Caíar depart - Caíar!

Caíar under earth, under embankments, under stones!

The supposed circumstances which led to the composition of this satire are elaborated in the medieval Irish glossary Sanas Cormaic, compiled sometime around the

\footnotetext{
${ }^{23}$ This statement prompts the obvious caveat that many poets were highly trained, literate individuals, who would themselves have been responsible for recording much of the source material which today provides us with essential clues to the nature of their existence and livelihood. Thus the emphasis on the role of poets apparent in many medieval Irish sources for literature and law may be in great part the product of authorial bias, perhaps arising from the perceived need to continually justify a profession that brought with it considerable privilege and reward.

${ }^{24}$ Breatnach (I987: II4-I5, $\left.\$ 23\right)$.

${ }^{25}$ Denis Casey has drawn my attention to the verbal parallel of this line with the formulation of the legendary judge Morann's advice to the young king Feradach in Audacht Morainn $\$ 57$ (Kelly, I976: I8-I9), which states: Apair fris, fo-bá fo-beba, di-rá di-rera; co boí co bía, is ed to-fuicérthar. Ní flaith mani follnathar na gnímu-so, 'Tell him, he may die, he will die, he may depart(?), he will depart; how he has been, how he will be, that is what will be proclaimed. He is not a ruler unless he performs these deeds.'
} 
tenth century. ${ }^{26}$ This text recounts, by way of a substantial digression on an etymological interpretation of a single headword, how Caíar's scheming wife falls in love with the young poet Néide and plots to use his power of satire to get rid of the king. She tells Néide to ask Caíar for a knife which it is geis, or taboo, for him to give away; ${ }^{27}$ when the king naturally refuses Néide's request, the poet recites a satire against him which causes blemishes to appear on his face. The king flees in shame, his physical imperfection having rendered him unfit for rule, and Néide takes his place as king. ${ }^{28}$ Yet other sources reveal how satire can sometimes be counteracted by praise. For example, the acephalous poetico-legal tract Bretha Nemed Dédenach, which shares some common material with Auraicept na nÉces, opens in the middle of a tale about how the legendary chief poet Athirne unwisely satirizes the river Modarn (now the Mourne in County Tyrone), causing it to overflow its banks in retaliation; Athirne is then obliged to recite a praise-poem to the river in order to make it fall back to its original level. ${ }^{29}$

\section{Metrical faults and correctives in satire composition}

As a manual for poets-in-training, Auraicept na nÉces is central to our understanding of the pedagogy underlying the principles expressed in such literary and legal sources. The Auraicept's text and commentary deal mainly with elementary linguistic topics such as letters, syllables, verse-feet, and nominal gender, thus imitating the core contents of the Latin grammatical manuals from which the scholiasts drew much of their doctrine. Moreover, a significant portion of the accreted material associated with the Auraicept consists of declensional paradigms which outline case-forms for exemplary

\footnotetext{
${ }^{26}$ Meyer (I9I2: 58-60, \$698, s.v. gáire); trans. Russell (2008: 34-35). Paul Russell, Sharon Arbuthnot, and Pádraic Moran are currently completing printed editions, translations, and commentary as well as an online searchable database for a group of interrelated medieval Irish glossary-texts, including Sanas Cormaic. These glossaries comprise several thousand entries consisting of headwords followed by explanations that range from single-word definitions to extended narratives; many of these are concerned with linguistic and metrical matters. For the project database see http://www.asnc.cam.ac.uk/irishglossaries; for a general survey of Sanas Cormaic and the problems attendant upon such compilatory texts see Russell (I988).

${ }^{27}$ The significance of this tale as an example of kingship and taboo in early Irish literature is discussed by O'Leary (I988: 107).

${ }^{28}$ Blemishes were one of the potential 'magical consequences' suffered by victims of satire. Physical deformity as an impediment to kingship is a frequent topos in medieval Irish literature, and the resonance of this theme in the tale of Caíar and Néide renders the use of satire as a plot device all the more compelling. Compare, for example, the account given in the law-tract Bechbretha of how the king Conall Cáech was blinded in one eye by a bee (Charles-Edwards \& Kelly, I983: 68-7I, $\mathbb{S} \mathbb{S 3}_{30-33}$ ), or that given in the saga-text Cath Maige Tuired concerning king Núada's loss of an arm in battle and its subsequent repair by the medicinal deities Dian Cécht and his son Míach (Gray, I982: 26-27, \$I4).

29 A more complete version of this tale is preserved in a later (thirteenth-century) composition by the bardic poet Giolla Brighde Mac Con Midhe, who specifies that the issue of contention was the Modarn's refusal to provide Athirne with a salmon for his supper. The poem is edited and translated by Williams (I980: II8-27); for further discussion see Gwynn's notes to his edition of the sole surviving copy of Bretha Nemed Dédenach (I942: $57-58)$.
} 
nouns of all three genders (namely, masculine fer 'man', feminine ben 'woman', and neuter nem 'heaven'), as illustrated in Figure 2.

The length and complexity of the declensional tables vary considerably amongst the different manuscript copies of the Auraicept, although all versions of the text appear to contain at least some of this material. It is thus probable that the paradigms travelled separately from the original core matter of the Auraicept, but that when incorporated into the text they underwent a process of accretion similar to that which characterizes the commentary on other linguistic elements. Anders Ahlqvist (I983: 30) has suggested three main phases for the accretion of the paradigms, summarized here as follows:

I. The pattern of Latin declension was adapted to the description of Irish nouns of all three genders (e.g. nominative fer, genitive fir, accusative fer, etc.)

II. On the model of of fiur 'from the man' (itself an imitation of Latin a uiro, or the tendency in Latin grammatical manuals to precede a noun in the ablative case with the preposition a 'from'), the pattern was extended to other prepositional phrases of all three genders, leading to new 'cases' such as ifer 'ingressive singular' (i.e. the preposition $i$ 'in' $+f e r$ 'man', grammatically an accusative after the preposition).

III. Further extension took place, which included not only prepositional phrases but other linguistic elements as well, such as cíafer 'quis uir' (interrogative pronoun cía 'who' + fer 'man') and isfer 'est uir' (copula form is + fer 'man').

Elsewhere Ahlqvist argued that the logical motivation for this accretive process was the fact that Old Irish scribal practices rendered the language 'mildly polysynthetic', as spaces were inserted not between words as we know them currently (for example, ó fiur) but rather between stress groups that correspond to the major constituents of a sentence (giving ófiur)..$^{30}$ Thus ófiur is described by the Auraicept commentator as the 'ablative' case of fer (designated as fochslaid, from the verb fo-coisle 'takes away'), even though Irish lacks a morphologically distinct ablative case and the form in question, fiur, is usually considered to be a dative (which by the Old Irish period comprised the Indo-European ablative, instrumental and locative cases).

In some versions of Auraicept na nÉces, however, the declensional tables were further extended to include forms derived through the use of stylistic devices. For example, a commentator on the copy of the Auraicept in the late-fourteenth-century Book of Ballymote ${ }^{3 \mathrm{I}}$ compares the nominative singular fer with forms such as feer, described as a mhallrughudh, 'its slowing' (i.e. of the vowel in the word fer), or ser, described as a chendfochrus tuis, 'its change of initial'. ${ }^{32}$ Ostensibly these devices

\footnotetext{
30 Ahlqvist (1974), drawing on Borgstrøm (I968). For further remarks on Old Irish conventions of word division, see Thurneysen (1946: 24-25, \$34) and Tristram (2010).

${ }^{31}$ Dublin, Royal Irish Academy 536 (23 P I2), fos I7ora-I79rb; see also the discussion below, n. 6I.

${ }^{32}$ For the full paradigm of fer discussed here, see Calder (I9I7: I36-39, 11. I770-I804).
} 


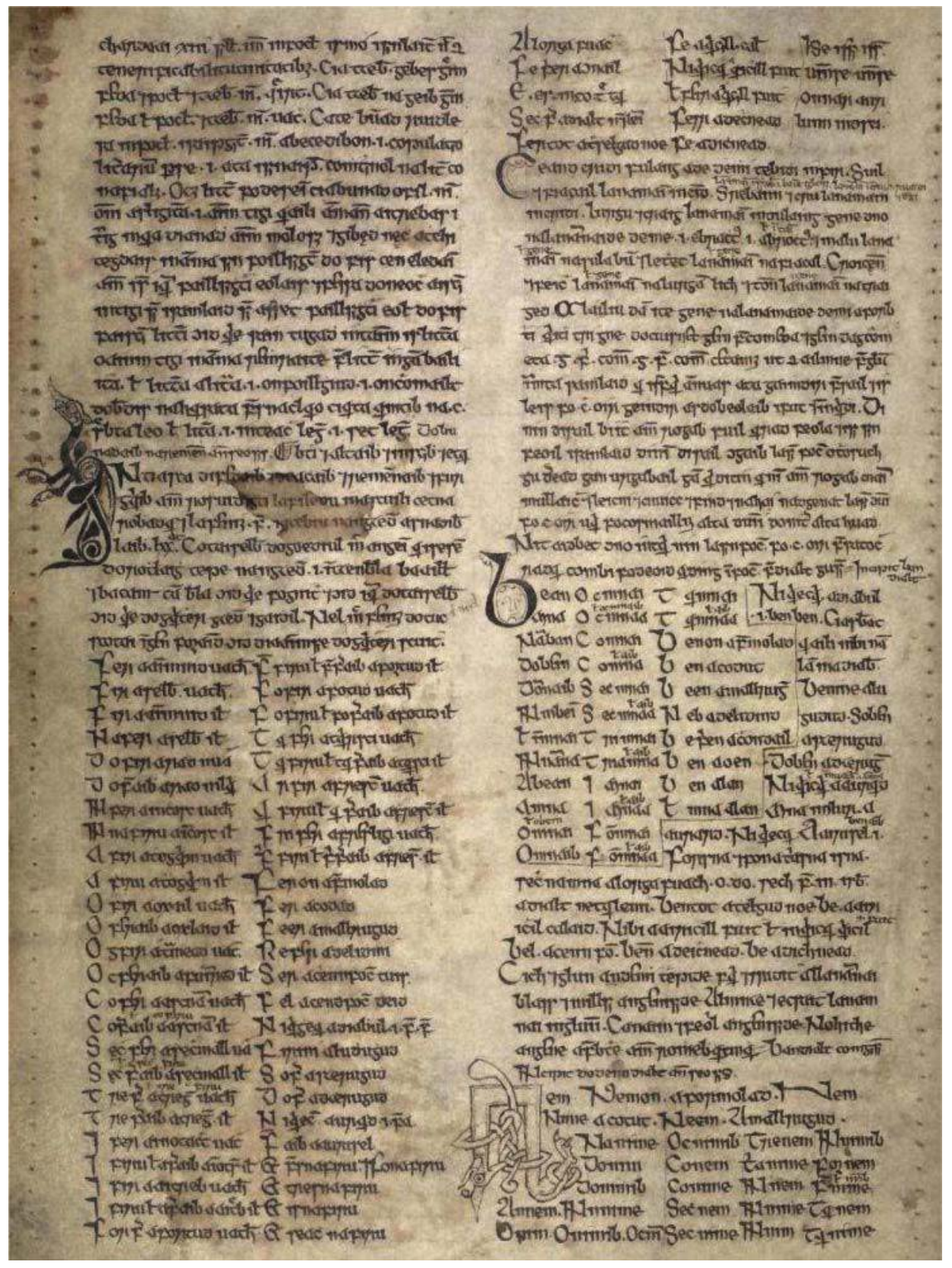

FIGURE 2 Nominal paradigm tables from Royal Irish Academy 536 (23 P 12), fol. 178v “The Book of Ballymote' (BB).

Image reproduced by permission of the Royal Irish Academy (C) RIA 
illustrate ways of dealing with metrical or alliterative exigency in poetic composition. Another dimension of their use is evidenced, however, by the commentary which grew up around a copy of the Amra Choluim Chille, or Irish eulogy of Saint Columba, found in the twelfth-century Bodleian library manuscript Rawlinson B 502. There it is claimed that such stylistic techniques could be employed in order to disguise words, with the implication that their meaning might then be accessible only to the initiated. This idea is clearly expressed in commentary on the word culu, which occurs at the start of the Amra's preface; the term is first glossed .i. carpat 'i.e. a chariot', and then further explained as follows: ${ }^{33}$

Culu, i. fortched sunn icond filid .i. dechned specialiter. Ar is cul in focol gnathach, acht ro thuill in fili .u. sunn do línad na filidechta nó do duaichnigud a luirg. Ar is inunn fortched ${ }_{7}$ fordorchad, ar is ed bís hi fortched, temligud ${ }_{7}$ duaichnigud na focul tria digbail ${ }_{7}$ tria thormach ${ }_{7}$ tria inchumscugud do dénam intib, 7 atat .iii. gné fair .i. dichned dechned $\left[{ }_{7} \text { formolad filed }\right]_{7}$ cennachros.

Culu: here the poet has an obscuration, i.e. specifically, a dechned. For cul is the usual word, but the poet added $u$ here to fill up the poetry, or to make its track hard to be known. For fortched is the same as darkening. For fortched consists in this, the obscuration and disguising of words by making in them diminution and augmentation and mutation. And there are four kinds of it, namely dichned and dechned and formolad filed and cennachros.

The scrambling or swapping of letters or syllables is central to medieval etymological method, and indeed similar descriptive terminology is frequently attested as a justification for the word definitions of early Irish glossary-texts. As is suggested by the above commentary on Amra Choluim Chille, such obscuration of language served the purpose of establishing literary analysis (and, in this case, elevated or poetic register) as the preserve of the learned. This inference is supported by the claim in the preface to In Lebor Ogaim, a tract on Ogam letters which occurs in close proximity to some manuscript copies of Auraicept na nÉces (as shown in Figure 3), 34 that the mythological figure Ogma invented Ogam script cuis airic derbad a intlechta ${ }_{7}$ co mbeth in bescna-sa ic lucht in eolais fo leth, sech lucht na tirdachta, na buicnechta, 'as a proof of his ingenuity, and that this speech should belong to the learned apart, to the exclusion of rustics and herdsmen'. ${ }^{35}$

\footnotetext{
33 Stokes (I899: I48-5I). On this topic see also Burnyeat (2007: 208-I3) and Kalyguine (I993: 43-75).

34 It has been edited and translated by Calder alongside the Auraicept (I9I7: 272-3I3).

35 Calder (1917: $272-73$, 11. 547I-73). The immediate source for the commentators' use of this idea may be Virgilius Maro Grammaticus' discussion of scinderatio fonorum, or the scrambling of words: on this and related topics see Law (1995: 83-96) and Watkins (1970). The concept that a hierarchical scheme of language usage underlies the authority of written text has, of course, a distinguished history in medieval Biblical exegesis and classical philosophy; compare for example Plato's discussion of etymology in the Cratylus (Fowler, I926), which distinguishes between the uninitiated 'ordinary masses' of language users and the so-called 'specialized artisans' or learned individuals who, by virtue of their training in etymological method, can better approximate the essential meaning of a word through decipherment of its superficial form.
} 


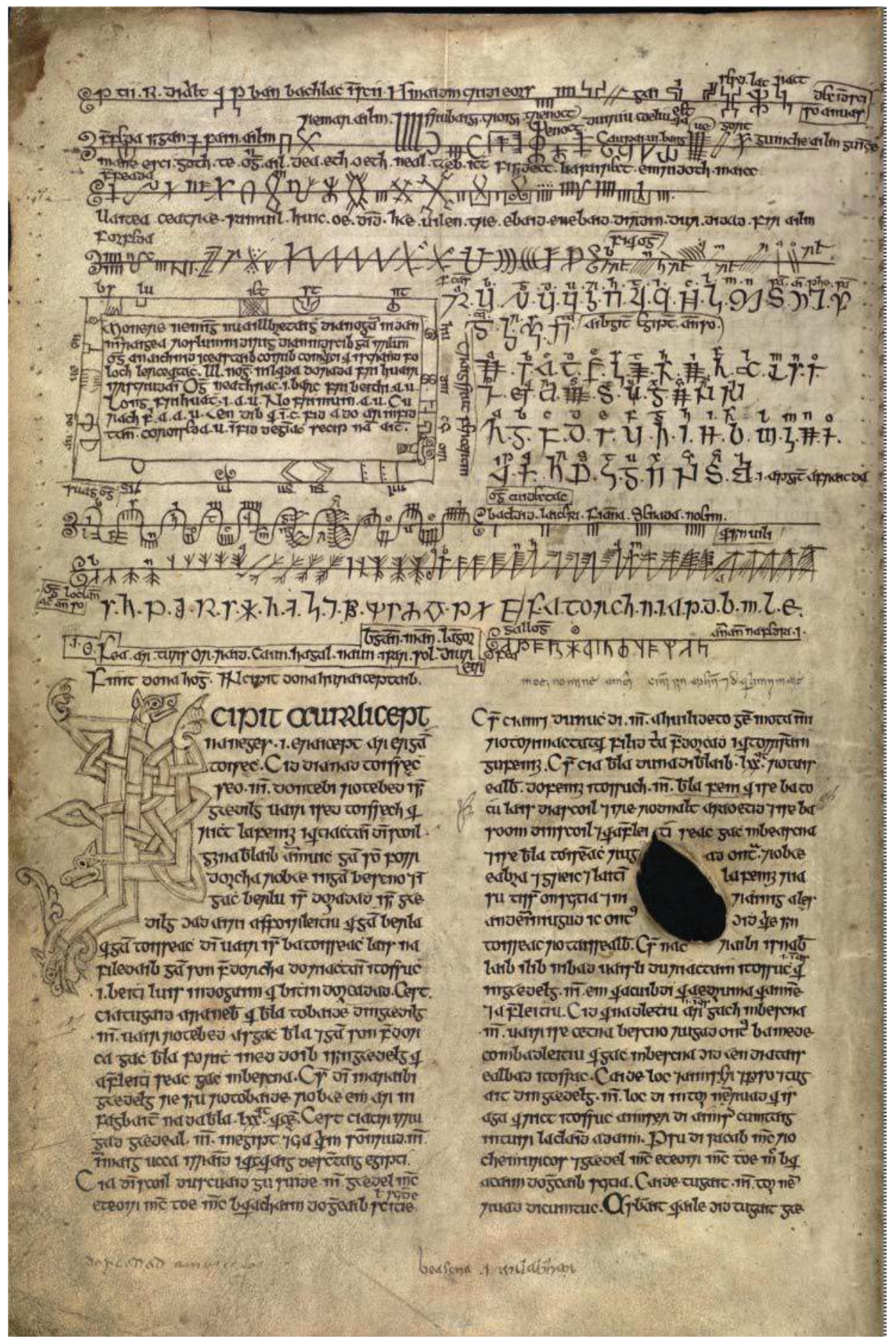

FIGURE 3 The Book of Ogam followed by the incipit to Auraicept na nÉces, in Dublin, Royal Irish Academy, 536 (23 P 12), fol. 170v 'The Book of Ballymote' (BB).

Image reproduced by permission of the Royal Irish Academy (C) RIA 
Similar stylistic devices are also evidenced by Auraicept commentary and didactic verse pertaining to the trefocal, a word attested in literary and legal sources as the name for a type of poetic composition which served as a legally sanctioned vehicle for the use of satire. The term trefocal, which literally means 'three words' (tre'three' + focal 'word'), refers to a poem combining both praise and satire which poets were expected to compose as part of a formal procedure by which they warned an individual of an impending full satire, therefore granting the accused an opportunity to avoid being satirized by settling the disputed issue. Crucially, it also stood as a legal requirement that the trefocal composition had to be metrically perfect in order for the poet's claim to be successful, much as a praise-poem offered to a patron had to be technically faultless in order for the poet to be entitled to his reward. ${ }^{36}$ In the Book of Ballymote Auraicept commentary, the term trefocal is consequently invoked as a means of illustrating compositional faults and correctives: ${ }^{37}$

Tref́ocal in so amal rocumsat na baird , na patreni .i. tref́focul cen cuail cnam. Cen craip cainti. Cen comman. Cen comsiudh. Cen dichur n-ecoir. Cen dallbhach dona dallbaigib. Cen ellach duna ellgib. Cenmota oenellach. Cen tar. Cen tamall. Cen faicit co cuibdius. Cen faicit cen chuibdius. Cen a focul frisin n-aprait filid frisuithi. Cen imsechfaidh indsci. Cen asneis for araile. Cen ecnach. Cen ecnuadh. Cen scath dofarce cuitbiud. Cen ae for an-ae. Cen saebsuidhiugud dialt ic frecra d'iarcomruc i n-urd bairdni. Conach in ceatharcubhaidh cummait baird. Cona friortud tecta forna focla masa oe congabhthar amal asbert: trefocal tachraid filid.

No (mar so) ita trefocal: cen chlaen, cen rudraigh, cen rofot, cen rogair, cen dimbrigh, cen forbrigh, cen ecnairc fri fregnairc, cen uathad fri ilar, cen ecenel, cen ec[om] uaim, cen ecuibdius, cen anocht .i. da locht deg na hirlabra in sin.

Dia nditen-sidhe cethri cenela fichet .i. co[r] raib ann: a formoladh, a codut, a mallrugud, a diabul, a deiliden, a oen, a lan, a lugugud, a saerughudh, a daerugud, a aurard, a airisel, a dhichneadh, a dhoichnead, a chonnail, a chendfochrus, a airchill fuit, a airchill calaid, a thelgudh noe, a urlonn insce, a hinsce mod, a lanamna deimi, a demi thepidhe, a ngen-side, co ndath 7 tothucht, co tomus fri fidh ${ }_{7}$ dech, reim ${ }_{7}$ forbad, alt 7 insci 7 etargoire ar cach cenel labartha dotuisim ar beolu duine, ar is a dealt domiter recomhrac, a recomrac domiter iarcomrac, a hiarcomrac dno feles, a feles domiter claenre, a claenre domiter luibenchosach, a luibenchosach domiter claidemnas, a claidemnas domiter bricht: ar comititer alta uad fri haltaib in duine, ar ita coic alta sescat ar tri cet in duine, a coic sescat ar tri cet aisti archetail, ${ }_{7}$ coic laithi sescat ar tri cet isin bliadain ${ }_{7}$ a coic sescat ar tri cet du luibib tre thalmain conastacmaing tlacht in trefocuil de quibus dicitur:

\footnotetext{
${ }^{36}$ Breatnach (2004: 25). For an edition and translation of the Middle Irish commentary that stipulates this condition of technical accuracy, as well as an account of the ritualistic procedure involved in reciting a trefocal poem, see Meroney (I953-58: 90-9I and I22-30). Tranter (I997a: 77-99) offers a brief survey of metrical and legal tracts related to the trefocal with some comparative evidence from Icelandic tradition.

37 Calder (I9I7: I48-5I, 11. I928-77). I have followed Calder's translation here, with some necessary minor corrections.
} 
Trefocal tacrait filid.

Trefocal tacrait filid

Do didin a n-indligid,

Ni mo na lucht cuibrind cland

Di neoch tuirmim notuigeand.

Sceith ocus gnuisi glana

Aincit lochta linmara,

Immar roscum Adna ogh,

$\mathrm{Ni}$ tarba gen a tintodh.

Da anocht deg is derb libh

Dlegait a fis na filid;

A main nocho n-fuair Etain,

Rofuaigh aib inn aircetail.

Da sciath dec is da ghnuis deg

Roordaigh dia n-imchoimet

$\mathrm{Na}$ lochta cen lomrim lac,

Da da comlin noscobrat. (etc.)

This is trefocal as the bards and the patreni $i^{38}$ have devised it, i.e., trefocal, without a heap of bones, without cramping of diction, without plagiarism, without sameness, without banishing ornament, without one of the dallbach [a kind of satire not conforming to ordinary metrics], without one of the ellach [a type of metre], save a single ellach, without disgrace, without pause, without rhyming accident, without unrhyming accident, without their word which poets call frisuithi [lit. 'in opposition'], without regular repetition of diction, without narrative on another subject, without blasphemy, without detraction, without a word that exceeds derision, without metre ( $a$ e) on non-metre (an-ae), without wrongly placing single syllables to answer as a trisyllabic word in the use of bard measure, so that there be not the four-rhyming quatrain which bards compose, so that there be no violation of law upon the words if it be a measure that is kept up, as he said: trefocal poets plead.

Or trefocal is without wrongness, without too many rhymes, without an over-long, without an over-short, without want of emphasis, without over-emphasis, without an absent to a present, without a singular to a plural, without false gender, without false alliteration, without false rhyme, without error, i.e., those are the twelve faults of composition.

To guard against these are twenty-four kinds, i.e. corraib ['points'?] there: its hyperbole, its hardening, its retarding, its reduplication, its inversion, its singleness, its full, its

$3^{8}$ The meaning of the poorly attested word patreni, which Calder leaves untranslated, is uncertain. The Dictionary of the Irish Language, s.v. patrene (http://www.dil.ie, accessed 4 November 20I0), suggests that it may have originated as a proper noun that subsequently came to be used as a generic term for a type of bard, but this is speculative due to the limited evidence. 
diminutive, its ennobling, its enslaving, its exaltation, its humiliation, its losing a final, its doubling a final, its internal division, its change of initial or final, its theft of a long, its theft of a hard, its man-throwing, ${ }^{39}$ its prefix of gender, its narration mode, ${ }^{40}$ its neuter couples, its selected neuters, their pairs, with colour and properties, with measure as regards letter, verse-foot, run, and accent, interval, gender, and comparison for every sort of speech that is produced on human lips; for it is from syllable that disyllable is estimated, from disyllable that trisyllable is estimated, from trisyllable in turn quadrisyllable, from quadrisyllable pentasyllable is estimated, from pentasyllable hexasyllable is estimated, from hexasyllable heptasyllable is estimated, from heptasyllable octosyllable is estimated: for the limbs of science are equal to the limbs of man, for there are 365 limbs of man, 365 measures of poetry, 365 days in the year, and 365 herbs through the earth,,$^{4}$ so that the protection of the trefocal encompasses them, de quibus dicitur:

\section{Trefocal poets plead.}

Trefocal which poets plead

To defend their lawlessness,

Is no more than a burden of a children's part

From something, I reckon, which they understand.

Shields and pure countenances

Ward off many blemishes

As perfect Adna has devised them,

It is no profit not to turn them.

Twelve 'errors', it is clear to you,

The poets must know them;

Etain has found no profit in them,

She has woven the beauty of poetry.

Twelve shields and twelve countenances

She has appointed to guard oneself against them,

The blemishes without a weak bare rhyme,

They succour them with double their number. (etc.)

39 The name for this rather dramatic-sounding corrective seems to derive from an Auraicept commentator's etymological analysis of the stylistic device by which one adds the syllable -tot to a noun (the paradigmatic example given being fer 'man'> fertot), which Kalyguine (I993: 55-56) describes as an analogous development of the Old Irish feature of suffixing pronouns to verbal forms. Thus one Auraicept commentator offers the (evidently heavily glossed) explanation: fertot a thelgud noe .i. a telgud duine, ar is nae duine, ut est dia ndama nae for tir .i. duleice in duine cessad fair, teit iarum dia fothrugud din uisciu, dolece don bruch sis isin usce, tot ol in tond fae i. fa tot dno a ainm in foghair sin doghni in tond: tott; tott dano a ainm forcmachta (no forcumascda) di sun, 'Fer tot, its telgud noe [literally 'flinging of a man'], for nae is a man, that is, if a man suffer on land, i.e. the man allows suffering on him, he goes afterwards to bathe himself in the water, he lets himself down the bank into the water, tot says the wave under him, i.e. tot was the name of that sound which the wave makes: tott; tott, then, is its onomatopoetic name, or mixed name from sound': see Calder (I9I7: I24-25, 11. I609-I4).

$4^{\circ}$ For discussion of the translation of indsce modh and some other devices, see Sims-Williams (2005).

${ }^{4 \mathrm{I}} \mathrm{I}$ discuss this triad of numerical symbolism in a forthcoming article (Hayden, 20II). 
The correctives in this passage of Auraicept commentary include techniques such as diminutives, hyperbole, and the addition and subtraction of letters or syllables, and thus echo the compositional vices and virtues of Latin grammatical doctrine. ${ }^{42}$ In this particular version of the Auraicept, moreover, a second list of devices (beginning with the words nó (mar so) ita trefocal, 'or thus is the trefocal') was apparently interpolated after the first, and the structure of this alternative list reflects the triadic nature of the trefocal composition for which knowledge of the techniques is required. The (presumed) interpolator first cites twelve compositional virtues, each of which is defined according to its opposite by using the word cen 'without' (e.g. cen rofot, 'without an over-long' and cen roghair 'without an over-short'). To these twelve faults are added twenty-four 'correctives', or techniques which serve to either increase or decrease the stylistic effect in question: for example, mallrugud 'slowing' and diabul 'reduplication' can remedy the problem of a syllable, line, or poem which is respectively either rofot or roghair. ${ }^{43}$

The Auraicept's commentary on the trefocal is a compelling illustration of how the opposites represented by metrical faults on the one hand and their correctives on the other might be seen to parallel the polarity between satire as a negative composition and its supposed 'antidote' of praise-poetry. This parallel is strengthened by the immediate juxtaposition in the Book of Ballymote manuscript of a didactic poem on the subject of trefocal composition, the first four stanzas of which are included in the quotation above. The poem begins with the declaration trefocal tacrait filid, "[it is] trefocal [that] poets plead', which introduces a series of verses outlining the rules applicable to composition of a trefocal poem. The didactic contents of the poem are largely a repetition of the devices listed in the Auraicept's preceding prose commentary, but the use of metaphorical imagery in the verse version of the doctrine is far more evocative. In depicting a 'shield' that wards off the 'blemishes', or faults, of poetry, the opening stanzas suggest that poets' technical knowledge constitutes a 'defence' for their use of satire in situations where it would otherwise be considered unlawful. The verses thus recall the treacherous motivation underlying Néide's satire against Caíar in Sanas Cormaic, where the poet's vindictive exercise of his artistic skill is justified on the grounds of his technical accuracy - a point which overshadows the fact that both his adulterous intention and the queen's revelation of Caíar's secret geis are manifestly illicit acts. Similarly, the defensive imagery of the trefocal poem calls to mind Athirne's prudent decision to recite a palinode to the river Modarn in Bretha Nemed Dédenach, an action which is described in the law-text as

\footnotetext{
${ }^{2}$ The classic example is the third part of Donatus' grammar; for its basic structure see later. The development of stylistic doctrine as part of classical grammar was hardly uniform, however, as has been shown by Baratin \& Desbordes (1987).

43 Thomas Charles-Edwards has also drawn my attention to the structural similarity between this passage and an Old Irish penitential of $c .800$, which follows an arrangement corresponding to the eight principal sins enumerated by John Cassian - namely that a list of vices is followed by the corresponding 'remedies' or virtues which the individual must aspire to achieve in order to balance out his or her disposition. For an edition and translation of the penitential see Gwynn (I9I4); for a revised translation see Bieler and Binchy (I963: 258-77).
} 
molad do-nig air, 'praise which washes away satire': ${ }^{44}$ for Athirne is portrayed as 'defending' himself against the threat of the river Modarn's retaliation by wielding the metaphorical 'weapon' of a metrically accurate praise composition.

\section{Metrical faults in related sources}

A list of stylistic devices similar to that found in the Auraicept commentary occurs in the poetico-legal tract Bretha Nemed Dédenach, which, as evidenced by its inclusion of the tale about the satirist Athirne, deals mainly with the rights and responsibilities of poets. ${ }^{45}$ The text's concern with rhetorical matters is salient, as can be illustrated by an excerpt on the properties of the voice headed de dliged goth $a^{46}$ in which the tract's compiler quotes from the Latin rhetorical manual Ad Herennium (attributed to Cicero in the medieval period): ${ }^{47}$

Até teora ranna gotha .i. méd, sonairte, 7 maoíthe, ut dixit Cicero. Figura vocis in tres partes diui[di]tur, in magnitudinem, in firmitatem, et in mollitudinem.

There are three parts of the voice, i.e. volume, strength and flexibility, as Cicero said. Voice quality is divided into three parts: volume, strength and flexibility.

Figure 4 illustrates a separate version of De dliged gotha which appears in close proximity to declensional material associated with the Auraicept. The list of compositional faults in Bretha Nemed Dédenach occurs after the pseudo-Ciceronian citation of the passage in question as part of a description of the qualities of bardic metre, and includes vices such as the incorrect use of gender markers, false rhyme, or inappropriate syllable length (Binchy, I978: III.II32.II-I6):

44 Breatnach (2006: 64-65); cf. Binchy (I978: III.IIII.Io).

${ }^{45}$ Kelly (I988: 268-69) clarifies that the text Bretha Nemed Toísech, 'the first Bretha Nemed', is the title used by legal scribes to refer to a text in London, British Library Nero A 7 (printed in Binchy, CIH VI.22II-2232) containing material on clerics, poets, and other professionals. The text Bretha Nemed Dédenach, 'the last Bretha Nemed', is that printed by Gwynn (1942) and Binchy (I978: III.IIII-38). Binchy (I955) suggests that these texts were the product of a Munster poetico-legal school. More recent analyses of the tradition include the discussions by Breatnach (1984) and Stacey (2007).

${ }^{46}$ The difficulty of translating dliged is discussed by Charles-Edwards (2003). Irish glosses on Latin grammatical texts typically use this term to render Latin ratio in its sense of 'phonological or grammatical process' (e.g. the phrase ratio analogiae, 'the rule of analogy', in reference to the derivation of grammatical forms). The heading de dliged gotha thus seems to refer to the 'rational order' or 'intelligible structure' of the voice. In native usage the semantic range of dliged primarily applied to law, where it could mean 'entitlement', 'right', or 'due'; the compilers of a poetico-legal text such as Bretha Nemed Dédenach were undoubtedly familiar with both senses.

47 Edited by Binchy (I978: III.II27.I4-I5) and Corthals (2007); the latter also addresses the nature and context of the material surrounding this quotation. Compare the statement in Ad Herennium III.xi.20 (Caplan, I954: I90-9I): Figura vocis ... dividitur in tres partes: magnitudinem, firmitudinem, mollitudinem, 'Voice quality ... has three aspects: volume, stability, and flexibility', which forms part of that text's discussion of pronuntiatio, or oratorical delivery. On the Irish material see also Tranter (I997b). 


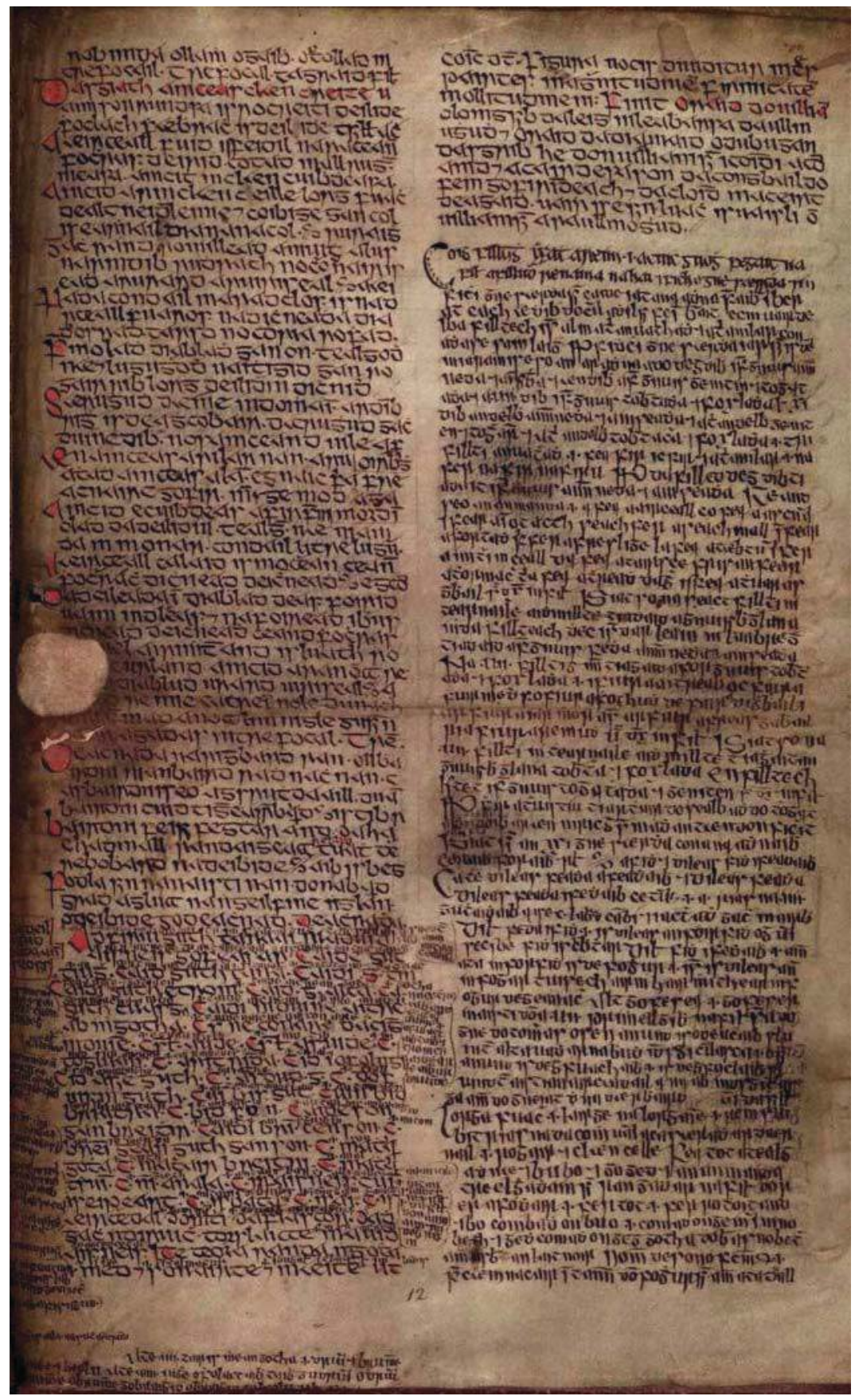

FIGURE 4 The end of the trefocal poem, followed by a copy of De dliged gotha (heavily glossed section) and uncolumned declensional paradigms (column B), in Dublin, Trinity College Library 1432 (E. 3. 3), p. 23 (D).

Image reproduced by permission of Trinity College Dublin (c) The Board of Trinity College Dublin 
Tomhus báirdne.

Cesc an ffil tomhus forsan mbairdne? Fil égin tomhus fri cluais, ${ }_{7}$ cóir nanála, 7 ar ná cam, ná rudhrach inne, na uathadh fria hiolar, na eccnairc fri freacnairc, na dimbríogh, no foirbhrígh, na rofad, na roghair, ná fresnés go naisnés, na écdhath, na eccenelus, na eccuibhdhius, na alt, (na) dialt i ccoimhreim innte ...

The measure of bard poetry.

Question, is there metre in bard poetry? There is indeed metre with respect to the ear, and evenness of breath, and the quality of which is neither uneven nor overlong, [and which does not] use a singular for a plural, or person-switching, ${ }^{48}$ or [show] want of emphasis, or over-emphasis, or [is] too long, or too short, or [uses] faulty address, or incorrect 'colour', or incorrect gender, or false rhyme, or a syllable or monosyllable in the same inflection ...

Significantly, 'bardic' metre is here said to be measured 'according to the ear and evenness of breath'. Those poets termed baird are frequently distinguished in poeticolegal texts from the more prestigious filid by their lack of professional training, and there is evidence in both Bretha Nemed Dédenach and Auraicept na nÉces to suggest that the distinction revolved around the question of literacy. ${ }^{49}$ For example, the former text explains that bards are exempt from the knowledge of writing that would have been an essential part of a fili's education: ${ }^{\circ}$

Gé ni dleghar dona bardaibh eolus i ffedhaibh ina i ndeachuibh dlegar doibh a cubhaid techta do urmuisi, ${ }_{7}$ do aithne fria cluais ${ }_{7}$ aignedh.

Though the bards are not required to have a knowledge of letters and syllables [or verse feet $],{ }^{51}$ they must be able to distinguish and recognise correct consonance by ear and by thought.

The stratification of language usage implied by the distinction between literate and illiterate poets in Bretha Nemed Dédenach is echoed in the Auraicept commentary's explicit recognition of different varieties of linguistic code or register. This specifies that the term gnáthbérla (gnáth- 'ordinary, customary' + bérla 'language, speech') refers to the language of everyday life, or that which, as Stacey has observed, is "“unmarked” by its lexical or grammatical eccentricities, (apparent) age, or association with any particular ritual or professional context. It is the ordinary language of

$4^{8}$ On this device see Sims-Williams (2005).

49 Breatnach (1987: 8I-89) argues that the technical meaning of the terms bard and fili varied significantly over the linguistic periods of Irish designated as Old (sixth to ninth centuries), Middle (tenth to twelfth centuries), and Early Modern (twelfth to seventeenth centuries). His evidence is compelling, although the biased nature of the surviving sources renders the practical implications of this distinction difficult to determine with certainty. On this question see also Simms (I998: 238-39).

50 Gwynn (I942: 43-44) and Binchy (I978: III.II32.20-22).

${ }^{5}$ Deach can mean both 'syllable' and 'verse foot'. On this and related issues, see my forthcoming article (Hayden, 2OII). 
Ireland and, as such, presumably accessible to all. ${ }^{52}$ Gnáthbérla is opposed to various 'marked' registers, including 'poetic language' (bérla na filed), the 'language of etymological analysis' (bérla etarsgarta), ${ }^{53}$ and what might be understood as a sort of 'legalese' (bérla Féne): ${ }^{54}$

It é cóic gné in bérla tóbaidi i. bérla Féne ${ }_{7}$ fasaige na filed 7 bérla etarsgarta 7 bérla fortchide na filed tríasa n-agaillit cách díb a chéle ${ }_{7}$ íarmbérla ...

These are the five kinds ('species') of the Selected Language: Language of the Irish, the Maxims of the Poets, Separated/Divided Language, Obscure Language of the Poets through which each of them addresses his fellow, and Cryptic Language.

The presence of doctrine pertaining to a hierarchy of linguistic usage in both the Auraicept and Bretha Nemed Dédenach emphasizes the importance of register and types of discourse for medieval Irish scholars as an indicator of the status or professional functions of individuals, and reinforces the idea expressed in the commentary to Amra Choluim Chille that stylistic devices were a means of achieving distinctions in this area. The delineation of 'marked' versus 'unmarked' linguistic registers implies that poets (and indeed other high-ranking professionals, such as jurists) had a special dispensation to employ stylistic devices in their speech, often for emotional effect, but presumably also to establish differing levels of authority according to how obscure and inaccessible their language was to the unlearned. Nevertheless, doctrine on stylistic matters also served to highlight the practical concern that poetic licence should be used with caution, lest an excess or a deficiency of devices detract from the quality of a given composition: all linguistic registers, whether simple or elevated, were presumably subject to this relative mean of appropriateness. Stacey has drawn attention to the legal implications of such a principle, noting for example that the law-tract entitled Gúbretha Caratniad ('The False Judgements of Caratnia') stipulates how poets are not entitled to payment for disingenuous praise, since this is equivalent to satire, while Bretha Nemed Toisech points out that obvious metrical or stylistic

52 Stacey (2007: 99). The doctrine pertaining to language register in the Auraicept and related texts was first discussed by Watkins (I970: 8-I7).

${ }^{53}$ Literally 'separated language', most likely in reference to the techniques of letter and syllable swapping, doubling, or removal, as considered in the above discussion of the Auraicept's declensional tables.

${ }^{54}$ Calder (I9I7: IOO-OI, 11. I302-04). Some accounts also include the aforementioned bérla bán, 'white language' of the Scriptures, as in the pseudo-historical prologue to the Senchas Már collection of law-tracts (see above, n. 2I). The reference to Irish as a bérla tóbaide, 'selected (literally 'cut out') language', in this passage reflects the Auraicept commentators' oft-cited claim that their language was constructed from elements of all the different tongues at Babel. See for example Calder (I9I7: 2-3, 11. 9-13): Cest, cia tugaid ara n-ebarar berla tobaide din Gaedilg? Ni ansa. Uair rotebedh as gach berla;7 gach son fordorcha gach berla, fo[fh]rith ined doib isin Gaedelg ara forleithi seach gach mbescna, 'Question, what is the reason why Irish should be called the "select" language? Not difficult. Because it was selected from every language; and for every obscure sound of every language a place was found in Irish owing to its comprehensiveness beyond every speech.' Bérla Féne 'language of the Irish' probably refers to some kind of language appropriate to jurists or similar professionals; compare for example the term fénechas, which denotes 'traditional customs and regulations', i.e. the laws of the ancestral Féni. On this topic see also Russell (2005: 405-07). 
faults can ruin a lawsuit or prosecution. ${ }^{55}$ An understanding of the boundaries of poetic licence was thus perceived as the criterion which distinguished a properly trained poet from a poorly trained one; this distinction was in turn the measure according to which laws of reward or compensation were drawn..$^{56}$

One final example will serve to illustrate medieval Irish stylistic doctrine related to that found in the commentary to Auraicept na nÉces. This is a much expanded list of metrical faults, complete with verse illustrations, which forms part of a collection of grammatical and metrical tracts composed for use in the bardic schools that were active between the thirteenth and seventeenth centuries. ${ }^{57}$ Irish linguistic scholarship in the early modern period, during which these tracts were produced, appears to have focused primarily on the development of a normative grammar for use in the composition of praise-poetry by professional writers, and accordingly the bardic grammatical and syntactical manuals present a written and literary language with archaic tendencies at some remove from spoken practice (typically termed 'Classical Irish'). ${ }^{58}$ The tracts do preserve examples of non-standard and dialectal language, though usually in a context where such conventions are condemned as faulty (lochtach) or unacceptable in literary composition.

It is notable, as several scholars have observed, that one metrical tract on the topic of the bardic curriculum cites Auraicept na nÉces as 'required preparatory reading' for students in the bardic schools, a point which is worth repeating here because it serves to highlight the continuity of tradition that prevailed between the Auraicept commentary and bardic material concerned with linguistic matters: ${ }^{59}$

Is hi tra cetus foglaím na cetbliadna .i. coeca ogum im certoghum ${ }_{7}$ airacept na neicsiné cona broluch ${ }_{7}$ cona réimendaib...

First, then, the learning of the initial year is (i.e.) fifty Ogams including Certogam and Auraicept na $n E$ Éces together with its prologue and its declensions ...

The preface to the bardic tract on metrical faults edited by Bergin strengthens the case for this continuity, in so far as it cites many of the same poetic techniques and faults found in the Auraicept commentary concerned with the trefocal:

55 Stacey (2007: 8I and I07); for the text see Binchy (I978: VI.2I92.20-2I and 2199.23-24 = Thurneysen (I925: $309\left(\mathbb{S}_{4}\right)$ and $366(\mathbb{S}$ I) and VI.2224.27 respectively).

${ }^{56}$ Stacey has cogently analysed other literary evidence for the way in which distinctions of register that are premised upon differing degrees of stylistic skill could be seen to determine the inherent truth-value and authority of statements: a compelling illustration of this is the motif of false or erroneous judgements made by kings in early Irish literature (2007: 80-82).

57 Several of these tracts were edited, but never translated or annotated, by Osborn Bergin (I9I6-55). The collection includes a tract on the declension of nouns and adjectives, one on irregular verbs, one on abstract nouns, and the treatise on verse faults and correctives that is subject to examination here.

${ }^{58}$ For the nature and use of the Irish literary language at this period, see especially Ó Cuív (I980) and McManus (2004a).

59 Thurneysen (I89I: 32), trans. McLaughlin (2005: I23). 
Aig seo na lochta is coitc[h]eand teagaid in gach aisdi don dan .i. claen comhardudh claen uaitne, ${ }_{7}$ ataid na claenreanda romhaind, ${ }_{7}$ brisidh ${ }_{7}$ brulingeacht, anocht ${ }_{7}$ eguaim, caiche ${ }_{7} \mathrm{cu}$ mara, rudhrach ${ }_{7}$ rofad ${ }_{7}$ rood imarbhagha ${ }_{7}$ rood sloindte, roghirre ${ }_{7}$ raen 7 aindrem, aindrem ferindsge ${ }_{7}$ aindrem baininnsge ${ }_{7}$ aindrem illraiche ${ }_{7}$ rem i n-inadh uama [leg. anma $]_{7}$ uathadh re hilar ${ }_{7}$ ilar re huathadh ${ }_{7}$ claechlod aisde ${ }_{7}$ agallaim is faisnes 7 suidigudh loc[h]tach 7 berla lochtach ${ }_{7}$ sealbhad lochtac[h] ${ }_{7}$ comfocul .l. 7 gaidhealg loc[h]tach ${ }_{7}$ ferinnsgi do bhainindsgi ${ }_{7}$ bainindsgi do ferinnsgi ${ }_{7}$ claen airmh $[\mathrm{e}]_{7}$ claen airde ${ }_{7}$ claen comhaimsearda 7 claen crichadh loc[h]tach ${ }_{7}$ dunadh loc[h]tach.

These here are the most common faults that arise in poetic metres, i.e. faulty rhyme and faulty consonance, and the faulty verses are before us [below], and imperfect rhyme and brúilingecht [type of syllabic verse with imperfect rhyme and imperfect consonance], error and incorrect alliteration, caiche [literally 'one-eyed', describing rhyme between words identical in form and meaning] and cú mara [referring to a verse excerpt showing faulty rhyme], verse that has too many rhymes or is too long or has a fault of comparison or of a surname, is too short or has raen [a type of fault in consonance] and faulty inflection, faulty masculine inflection and faulty feminine inflection and faulty plural inflection, and inflection after a noun, and singular for plural and plural for singular, and changing of metre and conversing and narrating, and faulty arrangement and faulty speech, and a faulty possessive and compound, and faulty spoken Irish, and masculine for feminine and feminine for masculine and faulty composition and anachronism [having the same metrical time or length], and faulty ending and faulty closure.

Following this introduction is an extensive series of verse excerpts offering illustrative examples of each fault, including several errors that are not cited in the preface to the tract. Frequently the techniques in question are highly specific or obscure (in some cases they are merely named after a word or phrase in the stanza used to exemplify them); in such cases only a close study of the stanzas given in illustration will reveal the precise meaning of the faults subject to discussion. ${ }^{60}$

\section{The metrical faults of Auraicept na nÉces in their manuscript context: a comparative case study}

Having surveyed the nature and context of doctrine on metrical faults and correctives in related medieval Irish sources, the final section of this article will consider the implications that the above evidence has for our understanding of the manuscript transmission of Auraicept na nÉces. The following discussion will compare the arrangement of linguistic and legal material in just two manuscripts containing copies of the Auraicept, but it is hoped that even such a preliminary investigation might serve as a useful diagnostic for future analysis of the text. The first of the two manuscripts in question is the fourteenth-century Dublin, Royal Irish Academy 536

\footnotetext{
${ }^{60}$ Damian McManus has undertaken some study of these verse excerpts in a series of articles for the journal Ériu (McManus, I997; 2000; 2004b; 2005; 2008).
} 
(23 P I2), or the 'Book of Ballymote', which contains one of the versions of the Auraicept used by Calder for his edition and translation of what he called its 'short text' family. ${ }^{6 \mathrm{I}}$ As a consequence of its comparative accessibility - being the only version of both core text and commentary to the Auraicept for which we have a full edition and translation - it is this so-called 'short' family of manuscripts which is often cited by scholars in studies which draw upon both the text and the commentary of the Auraicept. At the risk of stating the obvious, however, it bears repeating that the compilatory nature of Auraicept material means that many valuable conclusions may be drawn about the scholarly intent and priorities of early Irish scribes on the basis of variations in the arrangement of manuscripts that were not available to Calder when he published his edition. Ahlqvist subsequently identified eleven full and eleven fragmentary copies of the Auraicept, only some of which had been used by Calder (Ahlqvist, I983: 22). Calder had distinguished between just two families of 'short' and 'long' Auraicept texts, but to this pair Ahlqvist added a third recension which he referred to as 'Group A' (opposed to 'Group B', which corresponds mainly to Calder's 'short family', and 'Group C', which corresponds to the 'long family').

The present study will compare the content and structure of the material surrounding the copy of Auraicept na nÉces in the Book of Ballymote (henceforth 'BB') with that surrounding a separate copy of the Auraicept found in a manuscript from the library of Trinity College Dublin (henceforth 'D'). ${ }^{62}$ The choice of D as a point of comparison to BB is justified on two grounds. First, D was unknown to Calder when he produced his edition in I9I7, and therefore the manuscript may yield fresh information about the treatise that is not apparent from Calder's published edition and translation. Second is the point that Ahlqvist, who was aware of D and made use of it for his edition of the original core of 'canonical' Auraicept material, classified D as belonging to his 'Group A' recension, or that version of the Auraicept which he considered distinct from either Calder's 'short-text' or 'long-text' families. Analysing the manuscript context of the copy of Auraicept na nÉces in D may therefore shed additional light on the relationship between the core text and its commentary and glossing.

\footnotetext{
${ }^{61}$ Calder (I9I7: xiii). This 'short text' family also includes Edinburgh, National Library of Scotland Gaelic I (72.2.I) ('John Beaton's Broad Book'); Dublin, Royal Irish Academy 535 (23 P 2) ('The Book of Lecan'); and Dublin, Royal Irish Academy I225 (D ii I) ('The Book of Uí Mhaine'). The Book of Ballymote was written mostly in Irish at Ballymote Castle, County Sligo, apparently under the patronage of the Meic Dhonnchadha of Corann. Significant to the present discussion is the fact that the manuscript's three scribes were all pupils of the McEgan family, which was renowned for its involvement with brehon law. On the manuscript's history see also Ó Concheanainn (I98I).

${ }^{62}$ Dublin, Trinity College Library, I432 (E. 3. 3) (s. XV-Xvi), 3aI-I6b23, only tentatively datable to the fifteenth or sixteenth century; see Abbott \& Gwynn (I92I: 307) and Ahlqvist (I983: 24-25). The abbreviation for this manuscript is in accordance with that used by Ahlqvist (I983:22), for ease of reference; however I refer to the Book of Ballymote copy, which Ahlqvist calls 'B', as 'BB' to avoid confusion with what he calls the 'Group B' recension to which it belongs.
} 
Ahlqvist classified the BB version of the Auraicept as part of his 'Group B' recension. He cited the principal distinction between Group A and Group B as being that the former seems to represent the shortest version of the Auraicept, omitting some prefatory material found in the Group B copies and breaking off with the words conige seo corp ind Auraicepta 'hitherto the main body of the Auraicept'. ${ }^{63}$ After this point, the manuscripts in Group B include significant additional commentary, most of which relates to nominal paradigms and stylistic devices. This includes the doctrine on verse faults and correctives that is articulated through the medium of prose commentary and the didactic poems on the subject of trefocal composition, as discussed above. However, much of this material relating to nominal paradigms and verse correctives does in fact occur in D, even though its arrangement in relation to the so-called 'main body' of Auraicept material identified by Ahlqvist, namely that ending at page $\mathrm{I}_{6} \mathrm{~b}_{23}$, is somewhat different. To give some perspective on the obscurity in which the contents of $\mathrm{D}$ have long remained hidden, one might consider the original account of this manuscript given by Abbott and Gwynn in their I92I catalogue of the Trinity College Dublin library holdings, which remained the only description of the manuscript's contents for a period of nearly ninety years. Here D is listed under the subject heading 'Grammar and Medicine', and its Auraicept material is described as follows: ${ }^{64}$

p.3. The Leabhar Ollamhan or Auraicept na nEices. This copy (not used in Calder's edition) begins like that in YBL facs., p. 217 (= No. I318, 500): ${ }^{65}$ Asbearad tra ubdair na $n$ Gaideal, but it differs considerably from both YBL and BB. The text is accompanied by a copious gloss which is ascribed (p. 3 m. sup.) to Cennfaolad mac Oiliolla. Ends incomplete with p. 24: Nem nime na nime, etc. $=$ BB. $330 \mathrm{~b} 45$. On p. $16 \mathrm{~m}$. inf., there is a note written perhaps by the scribe of this tract: As mór ion mageadh do Śeáan Ó siagail net (= beit) ag iaraig ollamnata a fine féin.

The next sequential item in D noted in Abbott and Gwynn's catalogue is a corpus of medical material beginning on page 25 of the manuscript. ${ }^{66}$ Ahlqvist's only clarification concerning the contents of the first half of $\mathrm{D}$ is his statement that the Auraicept material on pp. 3 aI-I6b24 of this manuscript is immediately followed by content which is largely poetico-legal in nature, some of which is reminiscent of Bretha Nemed Dédenach (Ahlquist, I983: 26):

${ }^{63}$ This corresponds in the Book of Ballymote text to the point found in Auraicept 1. I636 (Calder, I9I7: I26-27).

${ }^{64}$ Abbott \& Gwynn (I92I: 307). Binchy (I978: I.xxii) noted, for example, that the contents of D only came to his attention 'at the eleventh hour', when the Corpus Iuris Hibernici 'was almost ready for press'.

${ }_{5}$ The Yellow Book of Lecan: Dublin, Trinity College Library I3I8 (H. 2. I6) (s. xiv-Xv).

${ }^{66} \mathrm{D}$ thus consists of two separate parts that have been bound together. The first contains Auraicept na nÉces and related linguistic and legal material, but breaks off incomplete at the bottom of p. 24. The second contains medical material (namely an Irish translation of part of John of Gaddesden's Rosa Anglica and a commentary on part of Geraldus de Solo's Practica super nono Almansoris); this latter half is characterized by a distinct script and begins at the top of p. 25 (incorrectly catalogued in Irish Script on Screen, http://www.isos.dias.ie, accessed I4 October 20IO, as p. 24a). 
After the section giving $\mathrm{D}$ and the glosses and commentaries $\left(\mathrm{D}_{\mathrm{I} 2}\right)$, the same scribe (as in $\mathrm{D}$ and $\mathrm{D}_{\mathrm{I}}$ ) has written a certain amount of poetico-legal material, including some $(\mathrm{D}$, $23 a_{27}-b_{3}$ ) that looks of linguistic interest and is very similar to that printed by Gwynn in his edition of a similar tract.

However, the Irish Script on Screen project $^{67}$ has recently produced a more detailed catalogue of D's contents, pointing up the fact that a closer analysis of this manuscript can shed much light on the nature of the linguistic and legal material considered in this investigation. In particular, the present discussion will examine this more recent description of $\mathrm{D}$ with a view to understanding the extent to which its copy of Auraicept na nÉces corresponds to equivalent material in BB. Accordingly, the left-hand column of Table I provides a synopsis of the contents of the first half of D (namely that section containing the material relevant to this study), while the righthand column lists the (primarily) poetico-legal material surrounding the BB version of the Auraicept, as edited by Calder. The respective contexts of these two Auraicept copies can thus be best understood through a vertical reading of each column individually, though material which appears in both versions has been highlighted in bold in order to show the degree to which the material in the two manuscripts corresponds in order and content.

The evidence presented in this table reveals the different ways in which linguistic material relating to the training of poets might be arranged amongst status-texts concerned with their legal position in society. Of particular interest is the placement of the didactic poems dealing with the composition of the trefocal. In BB these are juxtaposed with the Auraicept commentary and the declensional paradigms, but in D both the trefocal poems and the paradigm material are separated from the so-called 'main section' of the Auraicept (pp. 3aI-I6b24) by an assortment of poetico-legal texts. This is not surprising, since there is evidence that trefocal material also travelled separately from the Auraicept proper, much like the nominal paradigms. ${ }^{80}$ The motivation for arranging this stylistic material alongside the Auraicept, the core of which deals with fundamental units of language, may derive from the common division of Latin grammars into separate sections dealing with basic linguistic elements and the parts of speech on the one hand, and material pertaining to faults and stylistic devices on the other. For example, Donatus' Ars maior is divided into three books, the first of which deals with voice/sound (vox), the letter/speech-sound (littera), syllables, metrical feet, accents, and punctuation, and the second of which discusses the parts of speech. The third book is devoted to figures of speech, and is divided into three chapters on 'faults' (barbarisms, solecisms, and a miscellaneous category of other 'vices') and three chapters on 'qualities' (metaplasms, schemes, and tropes). This third section commonly circulated separately in the medieval period

\footnotetext{
${ }^{67} \mathrm{http}: / / w w w . i s o s . d i a s . i e$.

${ }^{80}$ Calder (I9I7: 258-69, 11. 5057-54I4) has edited one such independently circulating copy of the trefocal from the Book of Leinster as part of his edition. For an account of other separate trefocal manuscripts, see Breatnach (I989).
} 


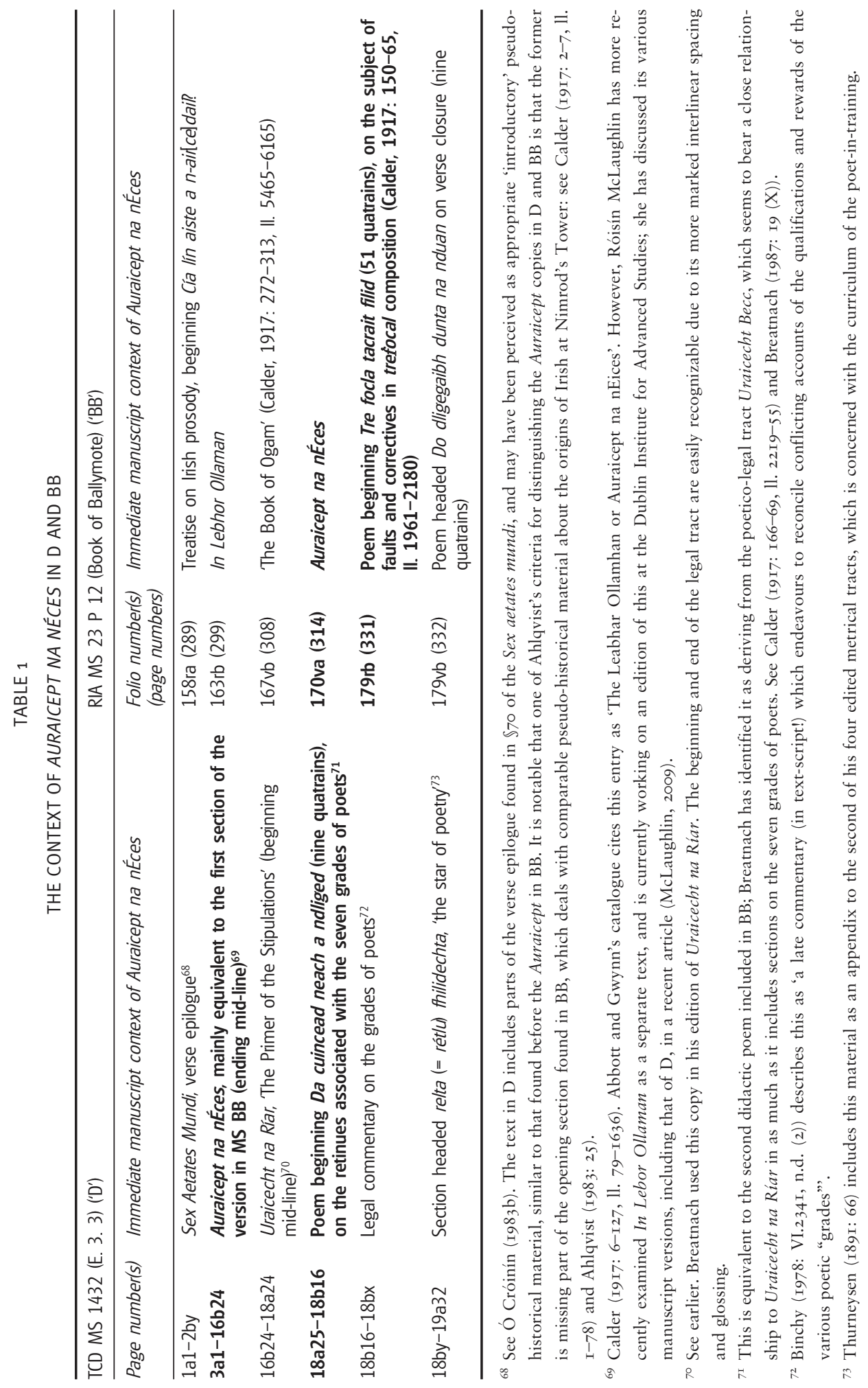




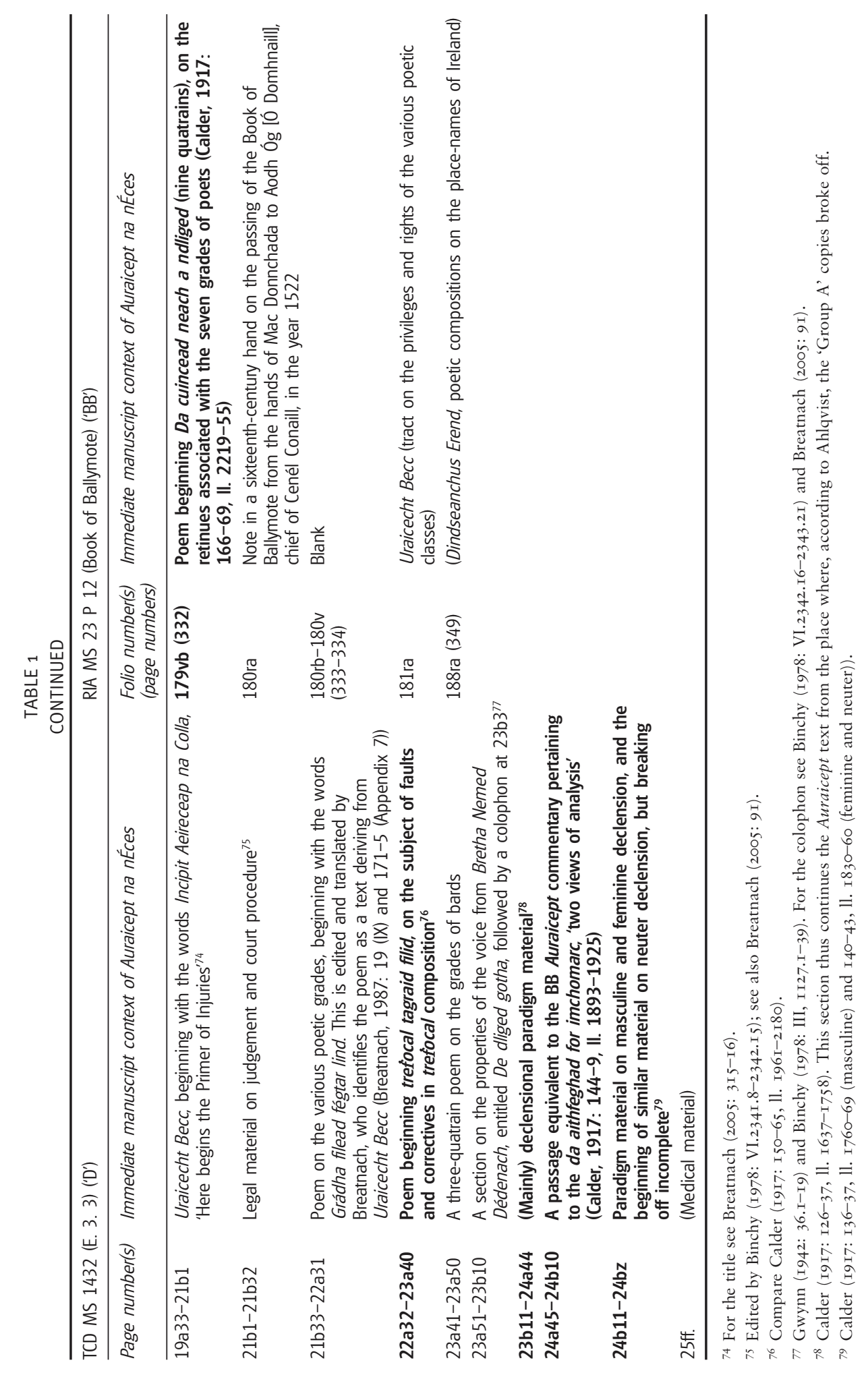


as a kind of Latin poetic manual, serving much the same purpose that the trefocal material would have done in relation to the Irish vernacular.

One final point regarding the above catalogue concerns the material on pp. 23 bi I$24 \mathrm{bz}$ of D. This was classified by Ahlqvist in his list of fragmentary Auraicept material as ' $\mathrm{D}_{3}$ ', or a section containing Auraicept material from 'Group B' (rather than 'Group A' to which he assigned the material on pp. 3aI-I6b23); he cited its correspondence to ll. $1637^{-1} 1925$ in Calder's edition of BB. ${ }^{81} \mathrm{~A}$ further breakdown of pp. $23 \mathrm{bII}-24 \mathrm{bz}$, however, shows that this additional Auraicept material from D omits two main sections of the corresponding commentary included in BB, summarized as follows:

I. Auraicept ll. I770I829 (ed. and trans. Calder, pp. I36-4I)

2. Auraicept 11. I86I-92 (ed. and trans. Calder, pp. $142-45)$
Material pertaining to the masculine declensional paradigm, as well as additional commentary on the corporeal properties of linguistic parts Material pertaining to neuter declension, followed by an additional passage on masculine declension

The second of these sections may simply constitute supplementary declensional material that was interpolated into $\mathrm{BB}$, as it does not present a great deal of doctrine which deviates from that in $\mathrm{D}$ and makes the commentary in $\mathrm{BB}$ seem repetitious. The first section of missing Auraicept commentary, however, is interesting from both a terminological and a doctrinal point of view, and its omission from this section of D may provide further evidence for the sources and chronology of the accreted commentary in the BB Auraicept. ${ }^{82}$ Moreover, it should be noted that further clues to the process of accretion in the BB Auraicept might be provided by an analysis of the marginal glossing on the main section of Auraicept material in D. ${ }^{83}$

This brief investigation has pointed up some of the ways in which improved understanding of the relationships that obtained between legal, poetic, and linguistic learning in early Ireland may illuminate the contents of both D and BB, and indeed vice versa. Variations in the ordering of linguistic and legal material in these two manuscripts indicate that medieval scholars did not view the distinctions between the two disciplines as having the same degree of significance that modern scholarship might wish to assign to them. Moreover, it illustrates that although it is a natural temptation to view Calder's edition of the Auraicept as a kind of 'canonical version' of both text and commentary from which other copies of the text deviate, such a tendency severely limits our conception of grammatical learning, pedagogical theory, and compilatory method in medieval Ireland. These potential limitations have become apparent in examining the D version of the Auraicept - importantly, a copy not known to Calder - from the starting point of its sections of commentary

\footnotetext{
${ }^{81}$ Ahlqvist (I983: 26) and Calder (I9I7: I26-49, ll. I637-I925).

${ }^{82} \mathrm{I}$ intend to examine this passage further in a forthcoming paper.

${ }^{83}$ As also noted by Ahlqvist in his discussion of this glossing (I983: 25-26).
} 
concerned with metrical faults and correctives. In Calder's edition, based primarily on $\mathrm{BB}$, not only does this doctrine appear to be incorporated seamlessly into the nominal paradigm material added to the end of the core Auraicept,${ }^{84}$ but the significance of its arrangement is highlighted by the juxtaposition of didactic poems on the same subject. In this way, the compilation of the BB Auraicept echoes the tripartite structure of many Latin grammars, which include stylistic devices as a concluding part of the grammatical curriculum. In D, however, the same didactic poems and much similar paradigm material occur at a further remove from what would seem to be the main body of Auraicept material, separated by various tracts on the legal status and privileges of poets. From this it is clear that, like the 'third part' of Donatus' grammar, the trefocal poems could also circulate as separate didactic 'manuals' that were independent of the Auraicept's other linguistic material. Finally, the relative proximity of legal and linguistic doctrine in manuscripts containing the Auraicept other than the two studied here is also a notable phenomenon, and one which serves to further highlight the value of such a study as a legitimate diagnostic for future research into the Auraicept's manuscript transmission.

\section{Conclusions}

It has long been established that medieval Irish grammatical and metrical doctrine sheds valuable light on our understanding of the social status of poets as powerful or influential figures who could, at least theoretically, acquire high status and considerable wealth by means of their compositions. Such status was dependent, however, on the legal stipulation that poets were expected to give value for money when trading their artistic wares, leading to an emphasis in many law-tracts and other literary sources on the necessity that their poems be devoid of technical faults. At the same time, it might be argued that the explicit articulation of stylistic rules also served the converse purpose of protecting artists themselves from the potential pitfalls of a legal code so reliant on the aesthetic judgement of the individual. The significance of this theme is apparent from the comparative abundance of extant early Irish doctrine concerned with stylistic devices, which includes metrical material from the bardic schools, passages from the poetico-legal tract Bretha Nemed Dédenach, didactic poems on the subject of trefocal composition, and scholia surrounding the core text of Auraicept na nÉces. Evidence for the practical application of this stylistic doctrine outside such pedagogical sources, moreover, further highlights a preoccupation with distinctions in register and usage as a central concern of linguistic study amongst literate members of medieval Irish society.

However, much work still remains to be done on Auraicept na nÉces and related texts from an editorial, contextual, and analytical point of view. The cursory codicological analysis of manuscripts D and BB offered above illustrates how the legal implications of achieving technical accuracy in poetic composition resulted in the

${ }^{84}$ As, for example, in Calder (I9I7: I36-39, 11. I770-I804). 
inclusion of material pertaining to verse faults and correctives among tracts of both a linguistic and a legal nature, and variations in the arrangement of this material should be taken into account when considering how to classify the accreted scholia associated with Auraicept na nÉces in a revised study of that treatise's textual transmission. The preliminary examination that has been undertaken here thus demonstrates that an up-to-date criticism of the Auraicept commentary in all its manuscript copies, both published and unpublished, may be greatly informed by critical studies not only of related material from the medieval Irish literary corpus, but also of the broader manuscript context in which copies of Auraicept na nÉces occur.

\section{References}

Abbott, T. W. \& E. J. Gwynn. I92I. Catalogue of the Irish Manuscripts in the Library of Trinity College, Dublin. Dublin: Hodges, Figgis.

Ahlqvist, Anders. 1974. Notes on 'Case' and Word-Boundaries. Ériu, 25: I8I-89.

- ed. and trans. 1982. The Early Irish Linguist: An Edition of the Canonical Part of the Auraicept na n-Éces, with Introduction, Commentary and Indices. Helsinki: Societas Scientiarum Fennica.

—. ed. and trans. 1984. Le Testament de Morann. Études celtiques, 2I: I5I-70.

—. I987. Varia I. Le Testament de Morann: Addenda et Corrigenda. Études celtiques, 24: 325.

- I988. Notes on the Greek Materials in the St Gall Priscian (Codex 904). In: The Sacred Nectar of the Greeks: The Study of Greek in the West in the Early Middle Ages, ed. by M. W. Herren \& S. A. Brown. London: Short Run, pp. I95-2I5.

Amsler, Mark. 1989. Etymology and Grammatical Discourse in Late Antiquity and the Early Middle Ages. Amsterdam: Benjamins.

Baratin, M. \& F. Desbordes. 1987. La 'Troisième Partie' de l'ars grammatic. In: The History of Linguistics in the Classical Period, ed. by Daniel J. Taylor. Amsterdam: Benjamins, pp. 4I-66.

Baumgarten, Rolf. 2004. Creative Medieval Etymology and Irish Hagiography (Lasair, Columba, Senán). Ériu, 54: $49-78$.

Bergin, Osborn. I9I6-55. Irish Grammatical Tracts I-V, Supplements to Ériu 8-10, I4 and I7.

Bieler, Ludwig \& D. A. Binchy. ed. and trans. 1963. The Irish Penitentials. Dublin: Dublin Institute for Advanced Studies.

Binchy, D. A. I955. Bretha Nemed. Ériu, I7: 4-6.

- ed. 1978. Corpus Iuris Hibernici, 6 vols. Dublin: Dublin Institute for Advanced Studies.

Borgstrøm, Carl. 1968. Notes on Gaelic Grammar. In: Celtic Studies: Essays in Memory of Angus Matheson I9I2-I962, ed. by James Carney \& David Greene. London: Routledge and Kegan Paul, pp. I2-2I.

Breatnach, Liam. 1984. Canon Law and Secular Law in Early Ireland: The Significance of Bretha Nemed. Peritia, 3: $439-59$.

- ed. and trans. 1987. Uraicecht na Ríar: The Poetic Grades in Early Irish Law. Dublin: Dublin Institute for Advanced Studies.

of Professor James Carney, ed. by Liam Breatnach, Kim McCone, \& Donnchadh Ó Corráin. Maynooth: An Sagart, pp. 7-3I.

- 2004. On Satire and the Poet's Circuit. In: Unity in Diversity: Studies in Irish and Scottish Gaelic Language, Literature and History, ed. by Cathal G. Ó Háinle \& Donald E. Meek. Dublin: School of Irish, Trinity College Dublin, pp. 25-35.

-2005. A Companion to the Corpus Iuris Hibernici. Dublin: Dublin Institute for Advanced Studies.

- 2006. Satire, Praise and the Early Irish Poet. Ériu, 56:63-84.

Breatnach, Pádraig A. I983. The Chief's Poet. Proceedings of the Royal Irish Academy, 83C.3: 37-79.

Burnyeat, Abigail. 2007. The Early Irish Grammaticus? Aiste, I: I8I-2I7.

Calder, George. ed. and trans. I9I7. Auraicept na n-Éces. The Scholars' Primer. Edinburgh: Grant. 
Caplan, Harry. ed. and trans. 1954. [Cicero], Vol. I. Ad C. Herennium, De ratione dicendi (Rhetorica ad Herennium). Cambridge, MA: Harvard University Press.

Carey, John. ed. and trans. 1994. An Edition of the Pseudo-Historical Prologue to the Senchas Már. Ériu, 45: $\mathrm{I}-32$.

Charles-Edwards, Thomas M. I995. Language and Society among the Insular Celts, AD 400-I000. In: The Celtic World, ed. by Miranda J. Green. London: Routledge, pp. 703-36.

- I998. The Context and Uses of Literacy in Early Christian Ireland. In: Literacy in Medieval Celtic Societies, ed. by Huw Pryce. Cambridge: Cambridge University Press, pp. 62-82.

- 2000. Early Christian Ireland. Cambridge: Cambridge University Press.

- 2003. Dliged: Its Native and Latinate Usages. Celtica, 24: 65-78.

—. \& F. Kelly. ed. and trans. 1983. Bechbretha: An Old Irish Law-Tract on Bee-keeping. Dublin: Dublin Institute for Advanced Studies.

Corthals, Johan. ed. and trans. 2007. Stimme, Atem und Dichtung: Aus einem altirischen Lehrbuch für die Dichterschüler (Uraicept na Mac Sésa). In: Kelten-Einfälle an der Donau, ed. by Helmut Birkhan. Vienna: Österreichischen Akademie der Wissenschaften, pp. I27-47.

Esposito, Mario. I9I2. The Knowledge of Greek in Ireland in the Middle Ages. Studies, I: $665-83$.

Fowler, Harold N. ed. and trans. 1926. Plato IV: Cratylus, Parmenides, Greater Hippias, Lesser Hippias. Cambridge, MA: Harvard University Press.

Freese, John Henry. ed. and trans. I967. Aristotle, Vol. XXII: The 'Art' of Rhetoric, rev. edn. Cambridge, MA: Harvard University Press.

Gray, Elizabeth A. ed. and trans. 1982. Cath Maige Tuired: The Second Battle of Mag Tuired. Dublin: Irish Texts Society.

Gwynn, E. J. ed. and trans. I9I4. An Irish Penitential. Ériu, 7: I2I-95.

-. ed. 1942. An Old Irish Tract on the Privileges and Responsibilities of Poets. Ériu, I3: I-60 and $220-36$.

Hayden, Deborah. Forthcoming 20II. The Anatomy of the Syllable in Irish Grammatical Terminology. Journal of Celtic Studies, 7 .

Herren, M. W. I980. On the Earliest Irish Acquaintance with Isidore of Seville. In: Visigothic Spain: New Approaches, ed. by E. James. Oxford: Clarendon, pp. 243-50.

- I98I. Classical and Secular Learning among the Irish before the Carolingian Renaissance. Florilegium, 3: II $8-57$.

Hofman, Rijcklof. 2000. The Irish Tradition of Priscian. In: Manuscripts and Tradition of Grammatical Texts from Antiquity to the Renaissance, ed. by Mario De Nonno, Paolo De Paolis, \& Lous Holtz. 2 vols. Cassino: Università degli Studi di Cassino, pp. I.257-87.

Hollo, Kaarina. 1996. Metrical Irregularity in Old and Middle Irish Syllabic Verse. In: Celtica Helsingensia: Proceedings from a Symposium on Celtic Studies, ed. by Anders Ahlqvist, Glyn Welden Banks, Riita Latvio, Harri Nyberg, \& Tom Sjöblom. Helsinki: Societas Scientiarum Fennica, pp. 47-56.

Irvine, Martin. 1994. The Making of Textual Culture: 'Grammatica' and Literary Theory 350-II00. Cambridge: Cambridge University Press.

Kalyguine, Victor. 1993. La Langue de la poésie irlandaise archaïque. Hamburg: Buske.

Kelly, Fergus. ed. and trans. 1976. Audacht Morainn. Dublin: Dublin Institute for Advanced Studies.

-. I988. A Guide to Early Irish Law. Dublin: Dublin Institute for Advanced Studies.

Law, Vivien. 1995. Wisdom, Authority and Grammar in the Seventh Century: Decoding Virgilius Maro Grammaticus. Cambridge: Cambridge University Press.

Lindsay, William M. ed. I9I. Isidori Hispalensis episcopi etymologiarum sive originum libri XX, 2 vols. Oxford: Clarendon.

Luhtala, Anneli. 1995. On the Grammarian's Self-Image in the Early Middle Ages. In: History of Linguistics I993: Papers from the Sixth International Conference on the History of the Language Sciences, ed. by Kurt R. Jankowsky. Amsterdam: Benjamins, pp. II5-26.

McCone, Kim. 1984. Notes on the Text and Authorship of the Early Irish Bee-Laws. Cambridge Medieval Celtic Studies, 8: 45-50.

- 1989. Zur Frage der Register im frühen Irischen. In: Early Irish Literature - Media and Communication/ Mündlichkeit und Schriftlichkeit in der frühen irischen Literatur, ed. by Stephen N. Tranter \& Hildegard L. C. Tristram. Tübingen: Gunter Narr, pp. 57-97. 
McLaughlin, Róisín. 2005. Metres in Mittelirische Verslehren III. Ériu, 55: II9-36.

- 2008. Early Irish Satire. Dublin: Dublin Institute for Advanced Studies.

- 2009. Fénius Farsaid and the Alphabets. Ériu, 59: I-24.

McManus, Damian. 1997. The Irish Grammatical and Syntactical Tracts: A Concordance of Duplicated and Identified Citations. Ériu, 48: 83-IOI.

- 2000. Varia IV: IGT Citations and Duplicate Entries: Some Additional Identifications. Ériu, 5I: I93-94.

- 2004a. The Bardic Poet as Teacher, Student and Critic: A Context for the Grammatical Tracts. In: Unity in Diversity: Studies in Irish and Scottish Gaelic Language, Literature and History, ed. by Cathal G. Ó Háinle \& Donald E. Meek. Dublin: School of Irish, Trinity College Dublin, pp. 97-I23.

- 2004b. Varia I: IGT Citations and Duplicate Entries: Further Identifications. Ériu, 54: 249-5I.

- 2005. Varia II: IGT Citations: Further Identifications. Ériu, 55: I45.

- 2008. Varia II: IGT Citations; More Identifications. Ériu, 58: I8I.

Meroney, Howard. I953-58. Studies in Early Irish Satire III: 'Tréfhocal fócrai'. Journal of Celtic Studies, 2: 59-I30.

Meyer, Kuno. ed. and trans. 1906. The Triads of Ireland. Dublin: Royal Irish Academy.

Meyer, Kuno. ed. I9I2. Sanas Cormaic. An Old-Irish Glossary Compiled by Cormac Úa Cuilennáin, King-Bishop of Cashel in the Tenth Century. In: Anecdota from Irish Manuscripts, ed. by O. J. Bergin, R. I. Best, Kuno Meyer, \& J. G. O'Keefe. Halle: Max Niemeyer, IV: I-I28 [repr. with Meyer's corrections added to the text, Felinfach, I994].

Ó Concheanainn, Tomás. I981. The Book of Ballymote. Celtica, I4: I5-25.

Ó Cróinín, Dáibhí. I983a. The Irish Provenance of Bede's Computus. Peritia, 2: 229-47.

- ed. and trans. 1983 b. The Irish Sex aetates mundi. Dublin: Dublin Institute for Advanced Studies.

Ó Cuív, Brian. I980. A Mediaeval Exercise in Language Planning. In: Progress in Linguistic Historiography, ed. by E. F. K. Koerner. Amsterdam: Benjamins, pp. 23-34.

O’Leary, Philip. 1988. Honor Bound: The Social Context of the Early Irish Heroic Geis. Celtica, 20: 85-107.

O'Riordan, Michelle. 2007. Irish Bardic Poetry and Rhetorical Reality. Cork: Cork University Press.

Poppe, Erich. I996. Die mittelalterliche irische Abhandlung Auraicept na nÉces und ihr geistesgeschlichtlicher Standort. In: Theorie und Rekonstruktion: Trierer Studien zur Geschichte der Linguistik, ed. by Klaus D. Dutz \& Hans J. Niederehe. Münster: Nodus, pp. 55-74.

- I999. Latinate Terminology in Auraicept na n-Éces. In: History of Linguistics I996, Volume I. Traditions in Linguistics Worldwide, ed. by David Cram, Andrew Robert Linn, \& Elke Nowak. Amsterdam: Benjamins, pp. I9I-2OI.

- 2002. The Latin Quotations in Auraicept na nÉces: Microtexts and their Transmission. In: Ireland and Europe in the Early Middle Ages: Texts and Transmission/Irland und Europa im früheren Mittelalter: Texte und Überlieferung, ed. by Próinséas Ní Chatháin \& Michael Richter. Dublin: Four Courts, pp. 296 -3I2.

Russell, Paul. 1988. The Sounds of a Silence: The Growth of Cormac's Glossary. Cambridge Medieval Celtic Studies, I5: I-30.

- 2000. Graece ... Latine: Graeco-Latin Glossaries in Early Medieval Ireland. Peritia, I4: 406-20.

- 2004. Quasi: Bridging the Etymological Gap in Early Irish Glossaries. In: A Companion to Linguistics: A Festschrift for Anders Ahlqvist on the Occasion of his Sixtieth Birthday, ed. by Bernadette Smelik, Rijcklof Hofman, Camiel Hamans, \& David Cram. Nijmegen: De Keltische Draak, pp. 49-62.

- 2005. 'What Was Best of Every Language': The Early History of the Irish Language. In: A New History of Ireland I. Prehistoric and Early Ireland, ed. by Dáibhí Ó Cróinín. Oxford: Oxford University Press, pp. 405-50.

- 2008. Poets, Power and Possessions: Some Stories from Sanas Cormaic. In: Law, Literature and Society, ed. by Joseph F. Eska. Dublin: Four Courts, pp. 9-45.

Simms, Katherine. 1998. Literacy and the Irish Bards. In: Literacy in Medieval Celtic Societies, ed. by Huw Pryce. Cambridge: Cambridge University Press, pp. 238-58.

Sims-Williams, Patrick. 2005. Person-switching in Celtic Panegyric: Figure or Fault? In: Heroic Poets and Poetic Heroes in Celtic Tradition: A Festschrift for Patrick K. Ford, ed. by Joseph F. Nagy \& Leslie E. Jones. CSANA Yearbook, 3-4. Dublin: Four Courts, pp. 315-26. 
Sims-Williams, P. \& E. Poppe. 2005. Medieval Irish Literary Theory and Criticism. In: The Cambridge History of Literary Criticism, Volume II. The Middle Ages, ed. by Alastair Minnis \& Ian Johnson. Cambridge: Cambridge University Press, pp. 29I-309.

Smith, Peter. ed. and trans. I994. Aimirgein Glúngel Tuir Tend: A Middle-Irish Poem on the Authors and Laws of Ireland. Peritia, 8: I20-50.

Stacey, Robin Chapman. 2007. Dark Speech: The Performance of Law in Early Ireland. Philadelphia: University of Pennsylvania.

Stokes, Whitley. ed. and trans. I899. The Bodleian Amra Choluimb Chille. Revue Celtique, 20: 30-55, I32-83, $248-89,400-37$.

Thurneysen, Rudolf. ed. I891. Mittelirische Verslehren. In: Irische Texte Series 3, ed. by Whitley Stokes \& Ernest Windisch, 4 vols. Leipzig: Hirzel, I: I-I82.

-

—. ed. I925. Aus dem irischen Recht III. Zeitschrift für celtische Philologie, I5: 302-70.

- ed. and trans. 1927. Aus dem irischen Recht IV. Zeitschrift für celtische Philologie, I6: I67-230.

- 1946. A Grammar of Old Irish. Dublin: Dublin Institute for Advanced Studies.

Tranter, Stephen. I997a. Clavis Metrica: Háttatal, Háttalykill and the Irish Metrical Tracts. Basel: Helbing \& Lichtenhahn.

- I997b. Ut dixit Cicero: A Note on Do dlighedh gotha. Studia Celtica Japonica, NS 9: II-I7.

Tristram, Hildegard. 20I0. Probleme bei der Quantifizierung morphologischer Komplexität im Altirischen. In: Akten des 5. Deutschsprachigen Keltologensymposiums, ed. by Karin Stüber, Thomas Zehnder, \& Dieter Bachmann. Vienna: Praesens, pp. 407-26.

Watkins, Calvert. 1970. Language of Gods and Language of Men: Remarks on Some Indo-European Metalinguistic Traditions. In: Myth and Law among the Indo-Europeans: Studies in Indo-European Comparative Mythology, ed. by Jaan Puhvel. Berkeley: University of California Press, pp. I-I7.

Williams, Nicholas J. A. ed. and trans. I980. The Poems of Giolla Brighde Mac Con Midhe. Dublin: Irish Texts Society.

\section{Notes on contributor}

Deborah Hayden obtained her PhD from the University of Cambridge in May 2010 and is currently working as a postdoctoral research assistant and lecturer in the Department of Anglo-Saxon, Norse and Celtic at Cambridge. In October 20I I she will begin a Junior Research Fellowship in Celtic at Christ Church, University of Oxford.

Correspondence to: Deborah Hayden, Department of Anglo-Saxon, Norse and Celtic, University of Cambridge, 9 West Road, Cambridge $\mathrm{CB}_{3}{ }_{9} \mathrm{DP}$, UK. Email: dhayden@alum.wellesley.edu 